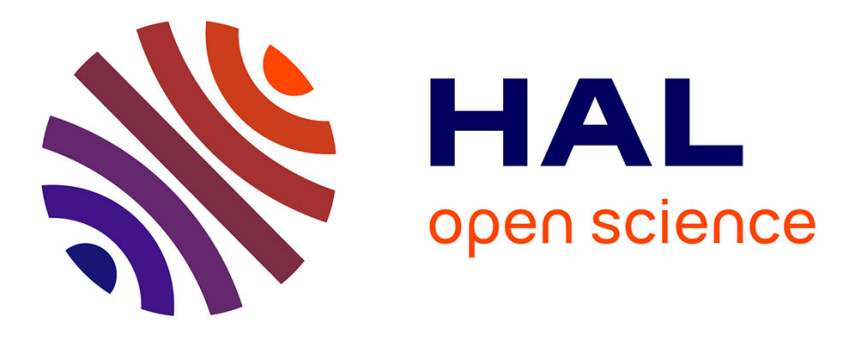

\title{
Modified Indulines: From Dyestuffs to in vivo Theranostic Agents
}

Zhongrui Chen, Simon Pascal, Morgane Daurat, Laure Lichon, Christophe Nguyen, Anastasia Godefroy, Denis Durand, Lamiaa M A Ali, Nadir Bettache, Magali Gary-Bobo, et al.

\section{To cite this version:}

Zhongrui Chen, Simon Pascal, Morgane Daurat, Laure Lichon, Christophe Nguyen, et al.. Modified Indulines: From Dyestuffs to in vivo Theranostic Agents. ACS Applied Materials \& Interfaces, 2021, 10.1021/acsami.1c05933 . hal-03269501

\section{HAL Id: hal-03269501 https://hal.science/hal-03269501}

Submitted on 24 Jun 2021

HAL is a multi-disciplinary open access archive for the deposit and dissemination of scientific research documents, whether they are published or not. The documents may come from teaching and research institutions in France or abroad, or from public or private research centers.
L'archive ouverte pluridisciplinaire HAL, est destinée au dépôt et à la diffusion de documents scientifiques de niveau recherche, publiés ou non, émanant des établissements d'enseignement et de recherche français ou étrangers, des laboratoires publics ou privés. 


\title{
Modified Indulines: From Dyestuffs to in vivo Theranostic Agents
}

\author{
Zhongrui Chen, ${ }^{a}$ Simon Pascal, ${ }^{a}$ Morgane Daurat, ${ }^{\mathrm{b}}$ Laure Lichon, ${ }^{\mathrm{c}}$ Christophe Nguyen, ${ }^{\mathrm{c}}$ Anastasia \\ Godefroy, ${ }^{b}$ Denis Durand, ${ }^{c}$ Lamiaa M. A. Ali, ${ }^{c, d}$ Nadir Bettache, ${ }^{c}$ Magali Gary-Bobo, ${ }^{*, c}$ Philippe Arnoux, ${ }^{e}$ \\ Jean-François Longevial, ${ }^{a}$ Anthony D'Aléo, ${ }^{a}$ Gabriel Marchand, ${ }^{f}$ Denis Jacquemin, ${ }^{*, f}$ and Olivier Siri*,g
}

a Aix Marseille Univ, CNRS, CINaM, UMR 7325, Campus de Luminy, 13288 Marseille cedex 09, France.

b NanoMedSyn, Faculté de Pharmacie, 15 av Charles Flahault, 34093 Montpellier, Cedex 5 France.

c Univ Montpellier, CNRS, IBMM, UMR 5247, ENSCM, 34093 Montpellier, France.

d Department of Biochemistry Medical Research Institute, University of Alexandria, 21561 Alexandria, Egypt.

e Université de Lorraine, CNRS, LRGP, UMR 7274, 54000 Nancy, France.

f Université de Nantes, CNRS, CEISAM, UMR 6230, Nantes, F-44000 France

Keywords: Imaging, PDT, phenazinium, theory, in vivo, dyes

\begin{abstract}
The efficient, versatile and straightforward synthesis of the first $N$-alkyl analogs of induline 3B ( $\mathbf{8 a}$ and $\mathbf{8 b})$ is reported. Thanks to the introduction of lipophilic substituents and its attractive photophysical properties (far-red emission and production of singlet oxygen), phenazinium $\mathbf{8} \mathbf{b}$ can be used as theranostic agent and shows, at very low concentration (100 $\mathrm{nM}$ ), a remarkable ability to: $i$ ) image cells and zebrafish embryos with high quality under both mono $(514 \mathrm{~nm})$ and biphotonic (790 and $810 \mathrm{~nm}$ ) excitations, ii) efficiently and quickly penetrate cancer cells rather than healthy fibroblast, iii) induce a total or almost total cancer cell death in vitro and in vivo after illumination $\left(\lambda_{\text {exc }}=540\right.$ $560 \mathrm{~nm}$ ). The molecular structure of $\mathbf{8 b}$ is based on a triamino-phenazinium core only, with no need for additional components, highlighting the emergence of a minimalistic and versatile class of fluorescent probes for targeted photodynamic cancer therapy.
\end{abstract}

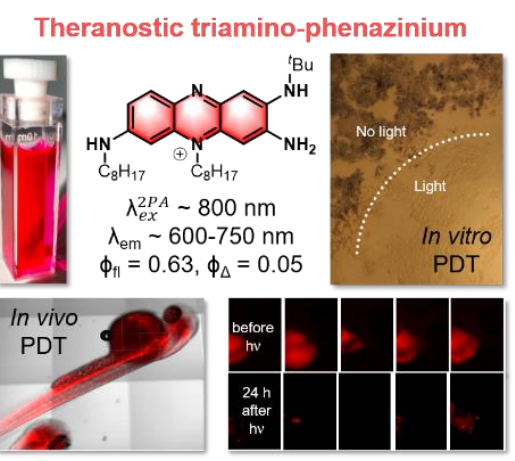

\section{INTRODUCTION}

Theranostic is a contemporary promising therapeutic approach for the treatment of cancer, combining therapy and diagnosis into a single compound. ${ }^{1-7}$ As such, theranostic molecules are mainly constituted of an imaging unit combined to a therapeutic agent within the same platform. They can be divided into two families: i) nanoparticles and/or macromolecular materials/polymers in which the diagnostic and therapeutic units are adsorbed, conjugated, or aggregated; ${ }^{8-16}$ ii) dual molecules, incorporating two distinct units (through a covalent bonding) for diagnosis and therapy. ${ }^{17-}$

${ }^{21}$ These multifunctional molecules operate intracellularly and can be activated by external stimuli such as light. However, these "multi-component" architectures suffer from difficult synthetic access and a high molecular weight, preventing their rapid diffusion across cell membranes, and limiting a reasonable water solubility for biological studies. ${ }^{22}$ An alternative to overcome these drawbacks is to use a minimalistic class of molecules that would be directly able to image and treat. To the best of our knowledge, only few compounds such as porphyrinoids, ${ }^{23,24}$ carbazoles, $^{25}$ cyanines ${ }^{26-28}$ or rylene-carboximides ${ }^{29}$ are able to achieve such effects, thanks to their high intrinsic fluorescence quantum yields (for cancer imaging), and photodynamic effect generating singlet oxygen (for treatment). Designing a new class of theranostic probes remains nevertheless a major challenge for chemists to access compounds combining three key features: 1) a minimalistic active core (low molecular weight), 2) structural parameters that allow a high degree of modifications (up to four positions) to fine-tune the properties., and 3 ) a versatile and straightforward synthesis.

One can turn to the triamino-phenaziniums (TAPs) of type 1, belonging to the induline family, which has a long history as dyestuffs, and was so far neglected for biological applications (Figure 1). ${ }^{30-33}$ Having excellent stability, these molecules, also known as induline $3 B$, induline spirit soluble or solvent blue 7 , have attracted a major attention in numerous applications ranging from photoreceptor or electrophotography agents to ingredient in color industry. ${ }^{34-38}$

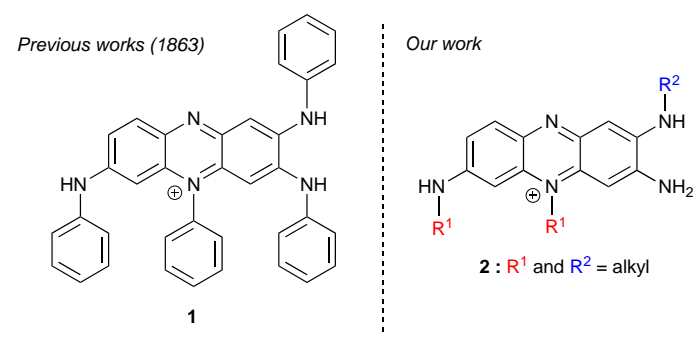

Figure 1. Induline 3B (1) and triamino-phenaziniums (2). 
This family of dyes - first reported by Dale and Caro as early as 1863 - can be obtained by condensation of aniline derivatives upon oxidation, considerably limiting the nature of the $N$-substituents (e.g., aryl) and the possibility to tune their molecular properties. ${ }^{30-33}$ Consequently, despite their attractive absorption properties and the possibility - in principle - to tune up to four positions (i.e. N-substituents), biological applications of these dyestuffs are hitherto unknown because of substantial limitations inherent to the presence of $\mathrm{N}$-aryl substituents (absence of lipophilic units to achieve an appropriate lipophilic/hydrophilic balance).

In this work, we prepared theranostic agents based on modified TAPs bearing $N$-substituents suited for in vivo anticancer therapy. The first $N$-alkyl analogs of induline 3B (2) are obtained by using an efficient, versatile and straightforward synthesis allowing their properties to be tailored (Figure 1). We demonstrate their remarkable biological activity at very low concentration for: $i$ ) cancer cells internalization with a better efficiency compared to healthy fibroblasts; ii) both one ( $1 \mathrm{hv}$ ) and two-photon (2 hv) imaging; and iii) treatment by photodynamic therapy (PDT), with an impressive cancer cell death both in vitro and in vivo upon illumination. Our combined experimental and theoretical study demonstrates the high potential of these TAPs acting as a promising class of "standalone" theranostic probes.

\section{RESULTS and DISCUSSION}

Synthesis and characterization. The synthesis of $\mathrm{N}$ substituted TAPs was achieved through an original synthetic pathway presented in Scheme 1, initiated with the gram-scale substitution of 2,4-difluoro-1-nitrobenzene 3 in presence of an excess of octylamine to afford the compound 4 with $96 \%$ yield.

Scheme 1. Synthesis of the triamino-phenaziniums $8 a, b$.

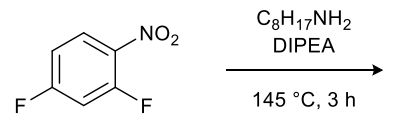

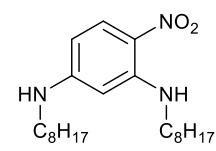

$4(96 \%)$

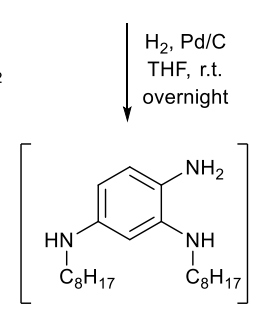

A

(not isolated)<smiles>NP[PH3]</smiles>

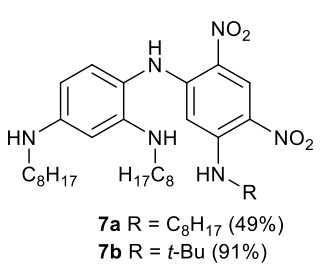

i) $\mathrm{H}_{2}, \mathrm{Pd} / \mathrm{C}$ $\mathrm{HCl}, \mathrm{MeOH}$, r.t. ii) $\mathrm{O}_{2}$ (air) (iii) aq. $\mathrm{HPF}_{6}$

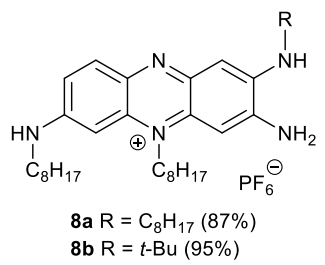

Although this synthetic step has been already reported in the literature with $60 \%$ yield, $^{39}$ the conversion has been sensibly improved by carrying out the substitution without solvent and using Hünig's base. The nitro function of $\mathbf{4}$ was reduced in a pressure bomb under 40 bars of $\mathrm{H}_{2}$ in presence of a catalytic amount of palladium over carbon $\left(\mathrm{H}_{2}, \mathrm{Pd} / \mathrm{C}\right)$. To prevent the spontaneous aerobic oxidation of the formed electron-rich intermediate A (appearance of a purple coloration), it was directly substituted in presence of one equivalent of 1,5 -difluoro-2,4-dinitrobenzene $(5)$ at $0{ }^{\circ} \mathrm{C}$ to afford the compound 6 in $84 \%$ yield (two steps). This latter compound was substituted with either octylamine or tertbutylamine and the corresponding products $\mathbf{7 a , b}$ were reduced in presence of $\mathrm{H}_{2}, \mathrm{Pd} / \mathrm{C}$ in acidic methanol. Further aerobic oxidation of the formed species resulted in an intramolecular cyclization that afforded the TAPs $\mathbf{8 a} \mathbf{a} \mathbf{b}$ which were isolated in gram-scale as hexafluorophosphate salts in $87-95 \%$ yields.

The X-ray structure determination of $\mathbf{8 b}$ confirms the presence of a tricyclic core incorporating an iminium nitrogen atom (N2) (Figure 2). Examination of the bond distances within the $\mathrm{N}(3)-\mathrm{C}(3)-\mathrm{C}(2)-\mathrm{C}(1)-\mathrm{N}(1)$ moiety shows a succession of single and double bonds (poor $\pi$-delocalization) whereas that of the $N(4)-C(4)-C(5)-C(6)-N(2)$ shows a full delocalization of the conjugated $\pi$ system.

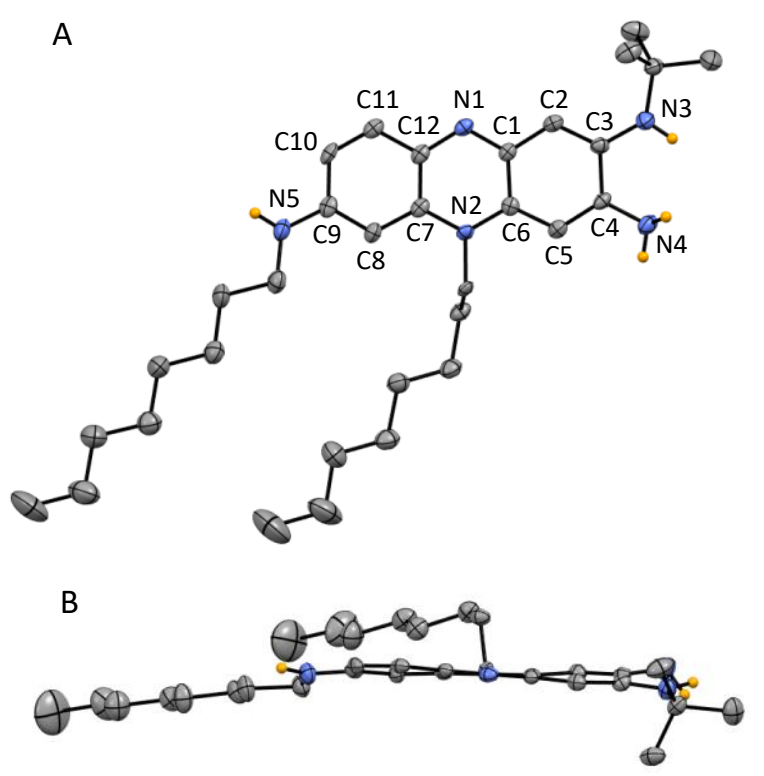

Figure 2. ORTEP views of $\mathbf{8 b}$ : A (top view), B (side view). Selected bond $(\AA)$ and angles $\left({ }^{\circ}\right)$ : $N(1)-C(1)$ 1.336(8), N(1)-C(12) 1.352(8), $\mathrm{N}(2)-\mathrm{C}(6) 1.371(8), \mathrm{N}(2)-\mathrm{C}(7) 1.370(8), \mathrm{N}(3)-\mathrm{C}(3)$ 1.380(8), N(4)$\mathrm{C}(4) 1.354(9), \mathrm{N}(5)-\mathrm{C}(9) 1.369(8), \mathrm{C}(1)-\mathrm{C}(2)$ 1.415(9), $\mathrm{C}(1)-\mathrm{C}(6)$ 1.437(9), C(2)-C(3) 1.364(9), C(3)-C(4) 1.466(9), C(4)-C(5) 1.384(9), $C(5)-C(6)$ 1.387(9), C(7)-C(8) 1.406(9), C(7)-C(12) 1.432(9), C(8)$C(9) 1.369(9), C(9)-C(10) 1.437(9), C(10)-C(11) 1.338(9), C(11)-$ $\mathrm{C}(12)$ 1.412(9), N(3)-C(3)-C(4) 116.4(6), C(3)-C(4)-N(4) 119.8(6), $\mathrm{C}(6)-\mathrm{N}(2)-\mathrm{C}(25) 120.1(5), \mathrm{C}(10)-\mathrm{C}(9)-\mathrm{N}(5)$ 118.3(6), C(1)-N(1)-C(12) $118.8(5), C(6)-N(2)-C(7) 121.0(5)$. Dimer of $\mathbf{8 b}$ in the solid state (bottom). The counter anion $\mathrm{PF}_{6}$ - has been omitted for clarity.

The latter observation clearly indicates the stabilization of the positive charge on $\mathrm{N}(2)$ by intramolecular delocalization. 
As a result, the strong conjugation of $\mathrm{N}(4)$ with $\mathrm{N}(2)$ induces a $s p^{2}$ character for the $\mathrm{N}(4)$ atom. These observations suggest that the degree of aromaticity is decreased in $\mathbf{8 b}$ compared to unsubstituted phenaziniums ${ }^{40}$ because of the external amino function (N4), stabilizing the positive charge. In addition, the $C(3)-C(4)$ bond length shows a single bond character (ca. 1.467 $\AA$ )), which supports the decrease of the aromaticity to promote the stabilization of the cationic charge. We underline that the central pyrazine unit is slightly distorted due to the presence of the alkyl substituent on the nitrogen atom N(2). In the solid state, the packing of $\mathbf{8 b}$ shows the formation of a pseudo dimer stabilized by $\pi-\pi$ interactions (see Figure S19 in the ESI). The two phenazinium units are parallel to each other with an interplanar distance of $3.437 \AA$, and positioned in a head-totail fashion to avoid the positive charges repulsion (the two centroids being distant by $3.649 \AA$ with a horizontal shift of $1.226 \AA$ ). This observation suggests the possible formation of J-aggregates in solution that should induce a bathochromic shift of the absorption wavelength (vide infra). ${ }^{41}$

Photophysical properties. 8b was used as model compound to investigate the photophysical properties of the $N$-alkyl analogues of induline 3B. The electronic absorption spectrum of phenazinium $\mathbf{8 b}$ in acetonitrile presents bands in the high energy range, and a broad band in the green region covering the $400-600 \mathrm{~nm}$ domain and peaking at $554 \mathrm{~nm}$, with a molar extinction coefficient $\left(\varepsilon^{554}\right)$ of $c a .43000 \mathrm{M}^{-1} \mathrm{~cm}^{-1}$ (Figures 3 and 4). This low energy transition appears to be moderately influenced by the polarity of the solvent (Figure S20): the peak absorption being shifted from $538 \mathrm{~nm}$ in toluene to $570 \mathrm{~nm}$ in DMSO ( $\Delta v$ ca. $1040 \mathrm{~cm}^{-1}$ ). Phenazinium $\mathbf{8 b}$ fluoresces in the red range with a maximum at $637 \mathrm{~nm}$ in acetonitrile, the band spanning towards the near-infrared range (cut-off emission ca. $780 \mathrm{~nm}$ ). This emission is characterized by a large quantum efficiency of 0.63 , generating a maximum brightness of 27000 $\mathrm{M}^{-1} \mathrm{~cm}^{-1}$.

The two-photon absorption (2PA) of $\mathbf{8 b}$ was measured using the two-photon-excited fluorescence technique in acetonitrile and reveals a near-infrared 2PA at $790 \mathrm{~nm}$, characterized by a non-negligible cross-section of 224 GM (Figure 3).

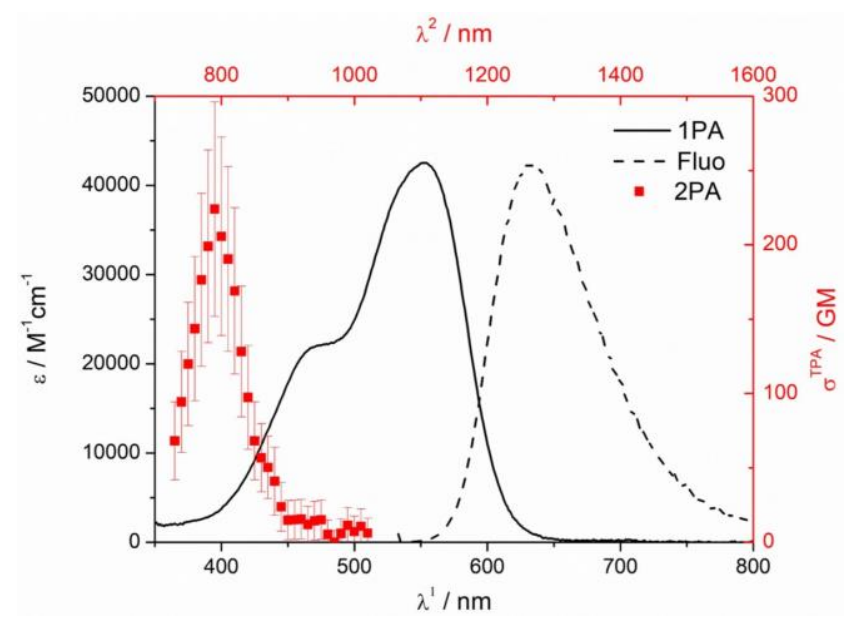

Figure 3. Two-photon (red), one photon (black line) absorption and normalized fluorescence (dotted line) spectra of $\mathbf{8 b}$ in acetonitrile.
Interestingly, the nonlinear absorption is not superimposable to the linear one, revealing that the $S_{0}-S_{2}$ transition excitation is responsible for the two-photon band. Although compound $\mathbf{8 b}$ is not formally centrosymmetric, this behavior is classical for quasi-quadrupolar polymethine structures. ${ }^{42,43}$ In a mixture of $n$-heptane and dichloromethane (DCM), $\mathbf{8} \mathbf{b}$ exhibits a bathochromically shifted absorption towards $570 \mathrm{~nm}$ accompanied by a decrease of its intensity with increasing proportion of heptane (Figure S21). This noticeable change can be attributed to the formation of $\mathrm{J}$ aggregates, presumably as dimer, as evidenced by X-ray analysis (Figure S19). In presence of triflic acid ( $\mathrm{TfOH}, 4.1$ equiv.), the absorption of $\mathbf{8 b}$ undergoes a remarkable bathochromic shift towards the red region, with a maximum found at $686 \mathrm{~nm}$ (Figures 4 and S22). This redshift is attributed to the mono-protonated species 9 (Scheme 2), featuring a dicationic pyrazinium core, confirmed by theoretical calculations (vide infra). A second protonation affording the tri-cationic species 10 induces a strong blue-shift of absorption towards $506 \mathrm{~nm}$ upon addition of a large excess of $\mathrm{TfOH}$. This band appears particularly narrow and intense $\left(\varepsilon^{506}=66000\right.$ $\mathrm{M}^{-1} \mathrm{~cm}^{-1}$ ), with a shoulder on the high energy side, as generally observed in cyanine-type absorption. ${ }^{44}$

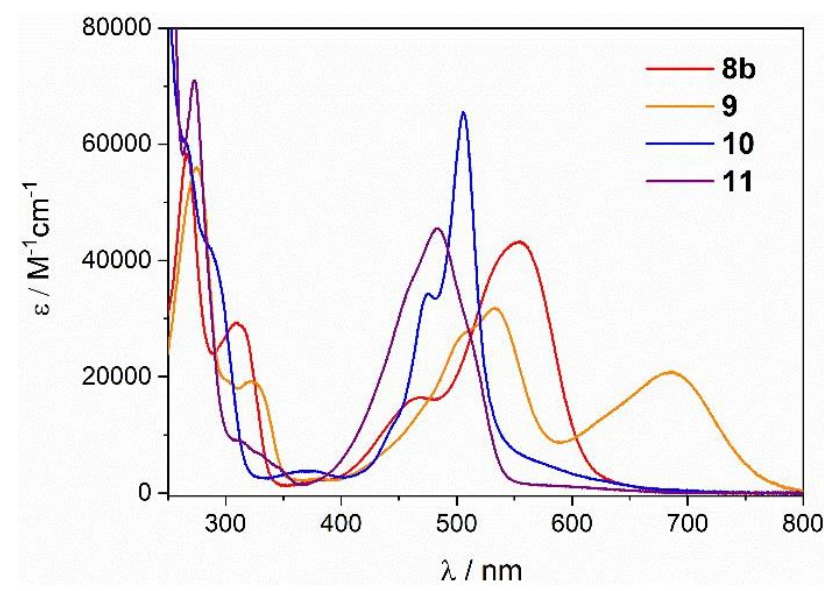

Figure 4. Electronic absorption spectra of $\mathbf{8 b}$ in acetonitrile and its different protonation species: $8 \mathbf{b}\left(\varepsilon^{554}=43000 \mathrm{M}^{-1} \mathrm{~cm}^{-1}\right), \mathbf{9}\left(\varepsilon^{686}=\right.$ $\left.21000 \mathrm{M}^{-1} \mathrm{~cm}^{-1}, \varepsilon^{533}=32000 \mathrm{M}^{-1} \mathrm{~cm}^{-1}\right), 10\left(\varepsilon^{506}=66000 \mathrm{M}^{-1} \mathrm{~cm}^{-1}\right)$, $11\left(\varepsilon^{483}=45000 \mathrm{M}^{-1} \mathrm{~cm}^{-1}\right)$.

The protonated forms $\mathbf{9}$ and $\mathbf{1 0}$ are non-emissive featuring a quenching of the fluorescence upon protonation of $\mathbf{8 b}$. In presence of DBU (up to 4 equiv.), the complete disappearance of $\mathbf{8 b}$ is monitored in favor of the formation of neutral quinoidal form 11, exhibiting absorption in the blue region, at $483 \mathrm{~nm}$, a common signature of 2,5-diaminobenzoquinonediimine derivatives. ${ }^{45-48}$ Moreover, fluorescence of $\mathbf{1 1}$ is blue-shifted to $550 \mathrm{~nm}$ and significantly quenched, with a quantum yield of 0.08 (Figure S23). Eventually, it is worth mentioning that $\mathbf{8 b}$ features a good photostability, its maximum fluorescence intensity being only slightly deteriorated upon prolonged visible light irradiation (see Figure S24). 
Scheme 2. Protonated species related to TAP $8 \mathrm{~b}$.

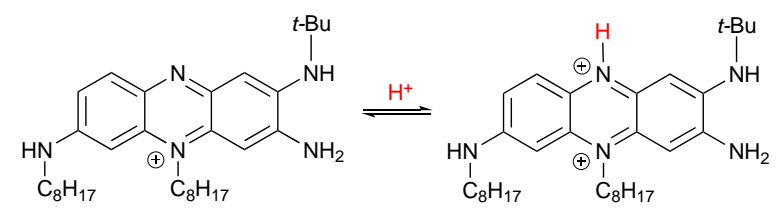

$8 b$

$-\mathrm{H}^{+}$

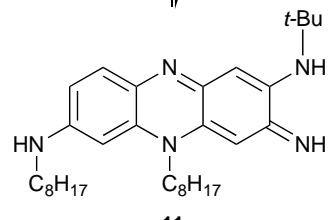

11

9 $\| \mathrm{H}^{+}$

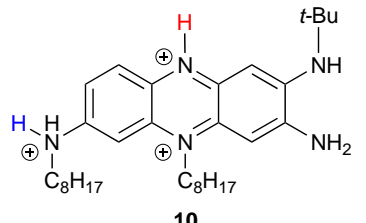

10

Theoretical studies. To establish a relationship between the optical signatures and the electron delocalization, firstprinciples calculations were performed on $\mathbf{8 a , b}$ and its (de)protonated forms 9-11. As can be seen in the SI (Figure S25-S27), we started with the simplified form of $\mathbf{8 a , b}$ wherein the alkyl chains have been replaced by methyl groups, such that $\mathbf{8 a}$ and $\mathbf{8 b}$ are equivalent and now stand for $\mathbf{8}$. We have investigated the relative energies of all possible tautomers for the (de)protonated (11) and protonated (9 and $\mathbf{1 0}$ ) forms. We observed that the structures displayed in Scheme 2 are indeed more stable than their alternatives by at least a few $\mathrm{kcal} \mathrm{mol}^{-1}$. All rings of compound 8 are aromatic $(\mathrm{NICS}(0)$ and $\mathrm{NICS}(1)<0$, see Figure S28), though significantly less than benzene. Upon deprotonation (11), the aromatic character of the two rings closest to the $\mathrm{N}$-deprotonated moiety completely disappears. This can be explained by the shortening of the $\mathrm{CN}$ deprotonated bond (amine to imine), which by resonance stretches out the adjacent $\mathrm{C}-\mathrm{C}$ bonds and reduces the homogeneity of the bond lengths along the cycles up to the center of the molecule (see Scheme 2). In contrast, the C-N bonds around the central $s p^{2}$ nitrogen atom are not significantly altered by protonation (9), and the aromatic character of the three rings is conserved. Upon di-protonation (10), the C-N bond adjacent to the ring on the left side of the molecule is elongated by $0.14 \AA$ and are rather equal, meaning that the latter cycle becomes more aromatic. The computed transition energies are listed in Table S1. For 8, the lowest transition is very bright and our best estimate is $528 \mathrm{~nm}$, which is slightly blue-shifted as compared to experiment (554 nm) due to the neglect of vibronic couplings in the calculation. When going to 9, theory predicts a strong redshift with the lowest transition at $725 \mathrm{~nm}$, also strongly allowed, which obviously fits the experimental trends (see Figure 4). Although the red-shift is a bit exaggerated, an effect likely due to the limits of the perturbative SOS-CIS(D) approach when the gap becomes very small. The doubly-protonated compound $\mathbf{1 0}$ is an interesting case: both TD-DFT and SOS-CIS(D) predict that the first excitation is almost forbidden $(f \sim 0.02)$ with a best estimate at $620 \mathrm{~nm}$, whereas the second excitation is very bright but located in a region close to the one of 8, i.e., $564 \mathrm{~nm}$. As can be seen in Figure 4, the experimental absorption of $\mathbf{1 0}$ indeed presents a tail in the 550-650 nm domain that we attribute to the first near-dark transition. Eventually, for 11, theory predicts a dipole-allowed $S_{0}-S_{1}$ excitation, but

significantly blue-shifted as compared to 8 (422 nm), likely due to the loss of the cyanine character. Again, the prediction is qualitatively in agreement with the measurements. The topology of the dipole allowed transitions responsible for the most redshifted absorption bands in all compounds are provided in Figure 5 (see also Figure S29 for the frontier orbitals).

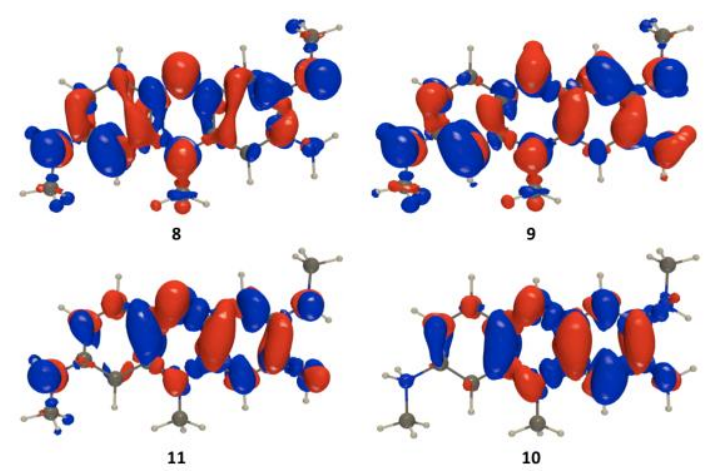

Figure 5. Electronic density difference plots upon the main dipoleallowed excitation in $\mathbf{8}, \mathbf{9}, \mathbf{1 0}$, and $\mathbf{1 1}$. The crimson (blueberry) lobes represent regions in which the density increases (decreases) in going from the ground to the excited state. Contour threshold: $0.001 \mathrm{au}$.

Clearly, these transitions are delocalized along the whole molecule through the $\pi$-conjugation, with an electronic displacement from the outside to the inside of the molecule. Indeed, the central nitrogen atoms appear in red (accepting) whereas the peripheral ones appear in blue (donating) almost systematically. The notable exception is $\mathbf{9}$ in which one notes that the $\mathrm{NH}_{2}$ group on the right-hand-side plays the role of an acceptor which promotes a stronger photo-induced CT than in the other forms, consistent with its redshifted absorption band.

Cell internalization. To determine the capability of $\mathbf{8 b}$ to be used for biomedical applications, we first needed to determine if it could be efficiently internalized into cultured human cells and if it could more efficiently target cancer cells than healthy cells. For this purpose, human breast cancer cells (MCF-7) and healthy dermal fibroblasts (HDF) were incubated for $24 \mathrm{~h}$ with increasing concentrations of $\mathbf{8} \mathbf{b}$ (Figure 6 ). In both cases, the percentage of stained living cells was then determined thanks to flow cytometry experiments. If we compare dose-responses between cancer and healthy cells (Figure 6A and B), the $0.5 \mathrm{nM}$ concentration was sufficient to stain $76 \%$ of cancer cells, while only $10 \%$ of healthy cells were stained in these conditions. In the same way, the comparative kinetics study between cancer and healthy cells demonstrated that incubation with $0.5 \mathrm{nM}$ of $\mathbf{8 b}$ for $24 \mathrm{~h}$, induced $90 \%$ and $24 \%$ staining of cancer cells and healthy cells, respectively (Figure 6C and D). The lipophilic alkyl chains paired with the cationic charge of $\mathbf{8} \mathbf{b}$ may enhance the passive diffusion across cell membranes and be consequently responsible for the efficient staining, as it is observed for various lipophilic cations. ${ }^{49}$ Moreover, these data demonstrated that $\mathbf{8 b}$ was more efficiently and more quickly internalized by MCF-7 cancer cells than healthy fibroblasts, suggesting a discriminatory effect of $\mathbf{8} \mathbf{b}$ with a better affinity for cancer cells. 

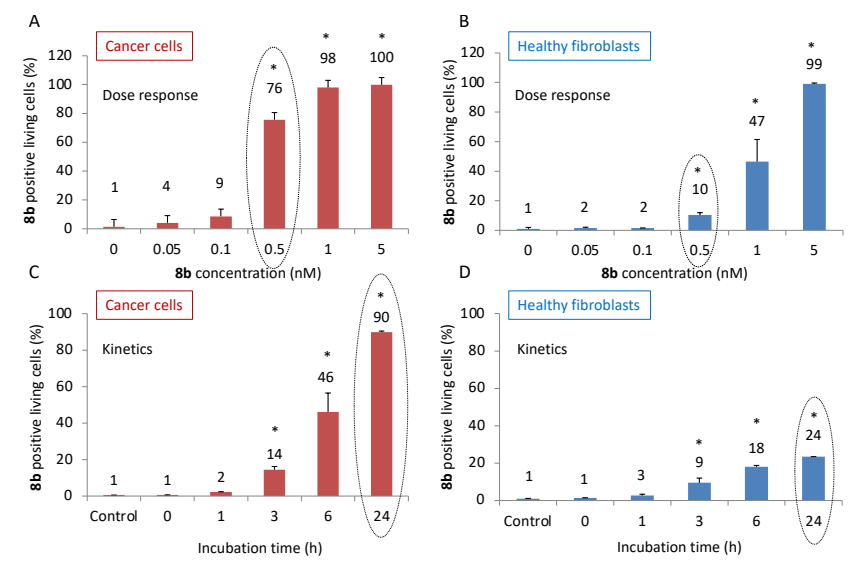

Figure 6. Internalization study of $\mathbf{8 b}$ into living cells. (A) Doseresponse study in MCF-7 breast cancer cells or (B) in healthy fibroblasts (HDF). (C) Uptake kinetic study in MCF-7 breast cancer cells or (D) healthy fibroblasts. $\mathbf{8 b}$ fluorescence was quantified inside the cells by flow cytometry. Data represent means \pm SEM of two experiments. ${ }^{*} \mathrm{p}<0.05$ statistically different from control or 0 .

In vitro cell imaging. We decided to establish if $\mathbf{8} \mathbf{b}$ could be observed by fluorescence microscopy inside cultured cancer cells.

\section{A}

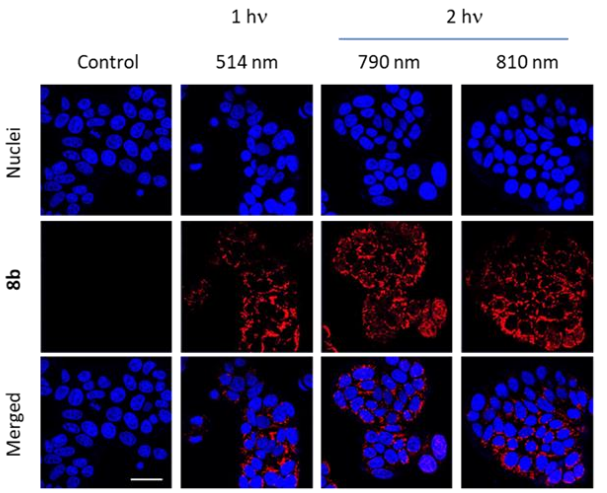

B
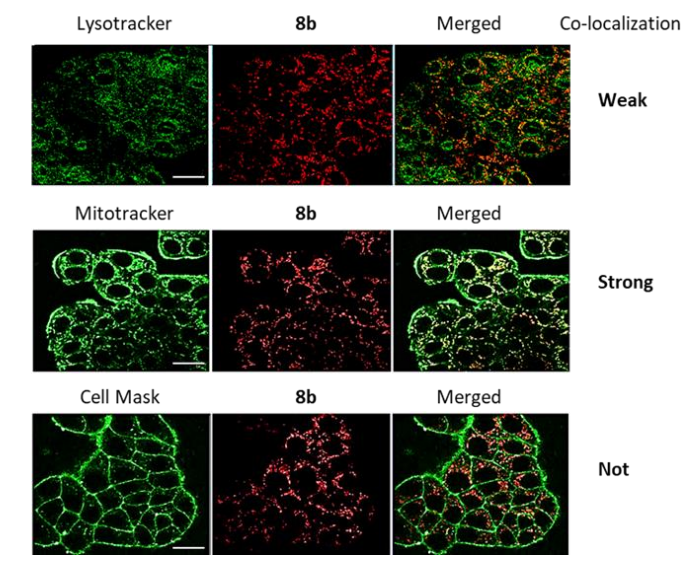

$8 b$ Merged

Figure 7. (A) Confocal microscopy imaging in living MCF-7 breast cancer cells incubated for $16 \mathrm{~h}$ with $\mathbf{8 b}(0.5 \mu \mathrm{M})$. One- or twophoton fluorescence imaging was performed under a $514 \mathrm{~nm}$ (1 hv) or 790 or $810 \mathrm{~nm}$ (2 hv) wavelength. (B) Co-localization study in MCF-7 incubated for $16 \mathrm{~h}$ with $\mathbf{8 b}(0.1 \mu \mathrm{M})$ performed under excitation wavelength of $514 \mathrm{~nm}$ for $\mathbf{8 b}, 504 \mathrm{~nm}$ for Lysotracker, $490 \mathrm{~nm}$ for Mitotracker and $522 \mathrm{~nm}$ for Cell Mask. Scale bar: 10 $\mu \mathrm{m}$.
For this, MCF-7 cells incubated $16 \mathrm{~h}$ with $\mathbf{8 b}$ at $0.5 \mu \mathrm{M}$ were visualized by confocal microscopy in presence of Hoechst 33342 to stain DNA of nuclei. Figure 7A demonstrates that under continuous laser excitation at $514 \mathrm{~nm}(1 \mathrm{hv}), \mathbf{8 b}$ is easily visible and strongly luminescent. Its localization around nuclei clearly shows the internalization of this compound in cancer cells. In addition, the two-photon microscopy ( $2 \mathrm{hv}$ ) was investigated using a pulsed laser (Chameleon lamp of confocal microscope). This study demonstrated that under pulsed laser excitation for biphotonic imaging (790 and $810 \mathrm{~nm}$ ), the potential of $\mathbf{8 b}$ was as strong as monophotonic imaging (514 $\mathrm{nm}$ ). Then, a co-localization study was performed in presence of organelles staining (lysosomes, mitochondria, nuclei). Living cells were incubated with a lower concentration of $\mathbf{8 b}(0.1 \mu \mathrm{M})$ for a finer and more precise staining, and with lysotracker or mitotracker or cell mask to determine the accumulation area of $\mathbf{8 b}$ inside the cells (Fig 7B). As demonstrated, a strong colocalization of $\mathbf{8 b}$ with mitochondria was obtained suggesting a targeting of this organelle and it is now well established that targeting mitochondria provides highly interesting therapeutic opportunities because of the crucial role of mitochondria in tumorigenesis. ${ }^{50}$

Photodynamic therapy. All together, these data suggest robust photo-activated properties of $\mathbf{8 b}$ under $1 \mathrm{hv}$ or $2 \mathrm{hv}$ excitation. Therefore, the capability of $\mathbf{8} \mathbf{b}$ to kill cancer cells under suitable excitation wavelength and power was investigated. First, the singlet oxygen generation quantum yield of $\mathbf{8 b}$ has been measured in acetonitrile and attains about 0.05. Noteworthy, deprotonation of $\mathbf{8 b}$ to form $\mathbf{1 1}$ does not induce significant variations of the singlet oxygen quantum yield. Whereas, in presence of triflic acid, the excitation in the blue-shifted band of 9 at $686 \mathrm{~nm}$ produces neither fluorescence nor singlet oxygen. Next, PDT experiments were performed on MCF-7 cells. They were incubated for $5 \mathrm{~h}$ with various concentrations of $\mathbf{8 b}$ and submitted or not to $1 \mathrm{hv}$ illumination, at $540 \mathrm{~nm}$ ( $4 \mathrm{x}$ objective, $20 \mathrm{~min}, 46 \mathrm{~J} \mathrm{~cm}^{-2}$ ). Results show that cells incubated with $10 \mathrm{nM}$ of $\mathbf{8 b}$ and submitted to illumination, exhibit $46 \%$ cell death (Figure $8 \mathrm{~A}$ ). Under the same conditions of light excitation, $100 \mathrm{nM}$ of $\mathbf{8 b}$ induced $98 \%$ of cell death. This highly efficient activity is illustrated by a contrast phase microscopy image of the treated and illuminated area after MTT [3-(4,5-dimethylthiazol-2-yl)2,5-diphenyltetrazolium bromide] assay, highlighting the almost total absence of living cells in the illuminated area (Figure $8 \mathrm{~A}$ ). We have also verified that this compound was relatively safe in the dark, the cell death becoming significant from $1 \mu \mathrm{M}$ after $72 \mathrm{~h}$ incubation time (Figure S30). Other wavelengths were tested for exciting $\mathbf{8 b}$ in MCF-7 cells such as $405 \mathrm{~nm}$ and $650 \mathrm{~nm}$ but no cell death was observed (data not shown). Furthermore, 2 hv excitation PDT was performed but no significant cell death was detected at $790 \mathrm{~nm}$ nor $810 \mathrm{~nm}$ (data not shown). The PDT efficiency was investigated on 3D culture model of MCF-7 cells and the reconstructed 3D images obtained by Imaris software show a reduction in the spheroids volume $48 \mathrm{~h}$ after PDT treatment (Figure $8 \mathrm{~B}$ ). Quantitative volume measurements demonstrate that without illumination, spheroid volume increase from $100 \%$ to $146 \% \pm 61 \%$ after 48 h. In contrast, light illumination caused a strong decrease in the 
spheroid volume, which pass to $100 \%$ to $59 \pm 11 \%$, $48 \mathrm{~h}$ after illumination (Figure 8C).
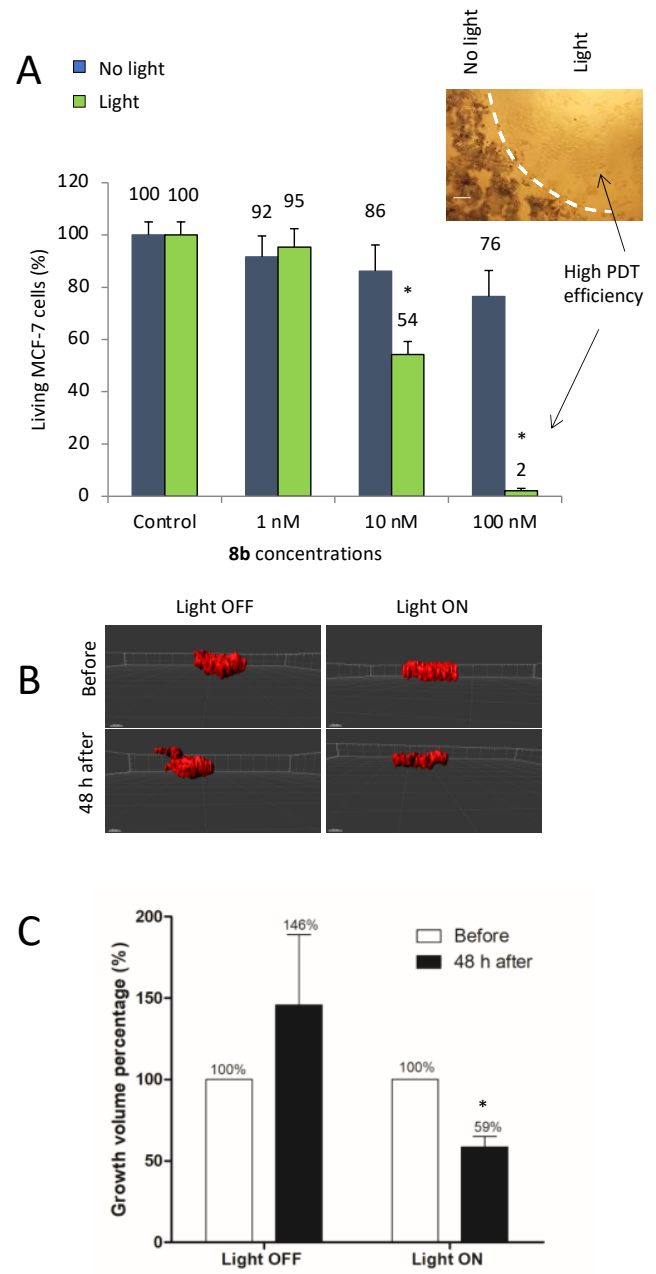

\begin{tabular}{|c|c|c|}
\hline $\begin{array}{c}\text { Volumes }\left(\boldsymbol{\mu m}^{3}\right) \\
\text { means } \pm \text { SD }(+06)\end{array}$ & Light OFF & Light ON \\
\hline Before & $1.29 \pm 0.46$ & $1.19 \pm 0.64$ \\
\hline 48 h after & $2.02 \pm 1.46$ & $0.66 \pm 0.29$ \\
\hline
\end{tabular}

Figure 8. PDT effects of $\mathbf{8 b}$ in MCF-7 breast cancer cells. (A) PDT effect of $\mathbf{8 b}$ in 2D MCF-7 cells treated with different concentrations of $\mathbf{8 b}$ during $5 \mathrm{~h}$ and illuminated or not at $540 \mathrm{~nm}$ for 20 min.*Statistically different from no light $(p<0.05)$. The picture enclosed showed illuminated and non-illuminated areas of cells treated with $100 \mathrm{nM}$, scale bar is $50 \mu \mathrm{m}$. (B) Pictures (from Imaris software) of 3D culture model of MCF-7 incubated with 1 $\mu \mathrm{M}$ of $\mathbf{8 b}$ for $24 \mathrm{~h}$ and illuminated or not at $540 \mathrm{~nm}$ during $20 \mathrm{~min}$. (C) Size of the spheroids was quantified (from Imaris software) before light excitation and 2 days after, the growth percentages are presented in bar graph, volumes in $\mu \mathrm{m}^{3}$ are presented in the table. *Statistically different from the volume before illumination $(p<0.05)$. All values are means \pm standard deviations of 3 independent experiments.

Another breast cancer cell line was studied to verify if the effect of $\mathbf{8 b}$ could also be applicable on a very aggressive model of cancer such as the triple negative MDA-MB-231 cells. As demonstrated in Figure $9 \mathrm{~A}, \mathbf{8 b}$ is efficiently internalized in these cells and well visible under a $1 \mathrm{hv}$ excitation at $514 \mathrm{~nm}$. In addition, under 2 hv excitation, at 790 or $810 \mathrm{~nm}$, the brightness of $\mathbf{8 b}$ is stronger. The PDT effect was studied on 2D and 3D culture models of MDA-MB-231 cells. Figure 9B shows that cells incubated with $\mathbf{8 b}(10 \mathrm{nM})$ for $5 \mathrm{~h}$ and submitted to a $1 \mathrm{hv}$ excitation at $540 \mathrm{~nm}\left(20 \mathrm{~min}, 46 \mathrm{~J} \mathrm{~cm}^{-2}\right)$ exhibit $84 \%$ cell death. This effect becomes stronger at $100 \mathrm{nM}$, with $99 \%$ of cell death. Spheroids from MDA-MB-231 were also produced to analyze the effect of $\mathbf{8 b}$ on $3 D$ cultures. In this case, one illumination of 20 min was insufficient for reducing spheroids volume. However, a second one, applied $24 \mathrm{~h}$ after induced a $38 \% \pm 11 \%$ volume decrease (Figure $9 \mathrm{C}$ ).

A

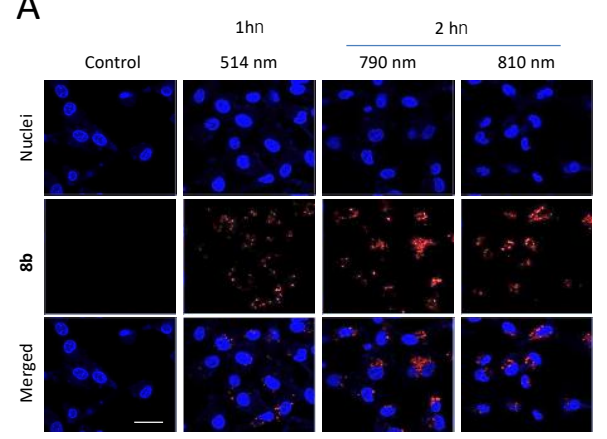

B

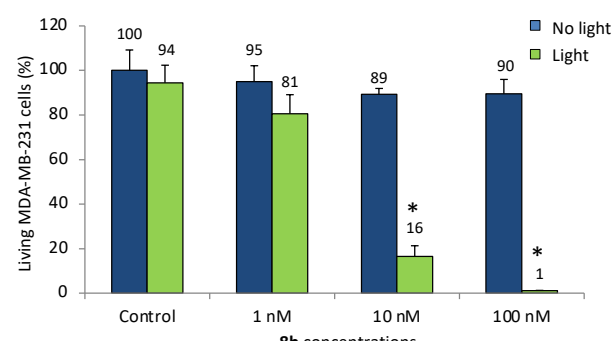

C

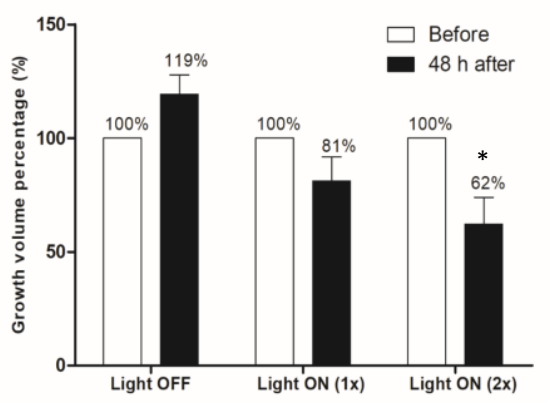

\begin{tabular}{|c|c|c|c|}
\hline $\begin{array}{l}\text { Volumes }\left(\mu \mathrm{m}^{3}\right) \\
\text { means } \pm \operatorname{SD}(+06)\end{array}$ & Light OFF & Light ON (1x) & Light ON (2x) \\
\hline Before & $1.11 \pm 0.23$ & $1.28 \pm 0.09$ & $1.17 \pm 0.30$ \\
\hline & $1 \pm 0.24$ & $1.03 \pm 0.11$ & $0.71 \pm 0.25$ \\
\hline
\end{tabular}

Figure 9. Imaging and PDT effect of $\mathbf{8 b}$ in MDA-MB-231 breast cancer cells. (A) $1 \mathrm{hv}$ and $2 \mathrm{hv}$ excitation fluorescence microscopy imaging of living MDA-MB-231 cells incubated for $16 \mathrm{~h}$ with 0.5 $\mu \mathrm{M}$ of $\mathbf{8 b}$. Nucleus and $\mathbf{8 b}$ appear in blue and red colors respectively, scale bar is $10 \mu \mathrm{m}$. (B) PDT effect of $\mathbf{8 b}$ in 2D cultures from MDA-MB-231 cells incubated with increasing concentrations for $5 \mathrm{~h}$, then illuminated or not at $540 \mathrm{~nm}$ during 20 min.*Statistically different from no light $(p<0.05)$ (C) PDT effect of $\mathbf{8 b}$ in 3D culture model of MDA-MB-231 cells incubated with 1 $\mu \mathrm{M}$ of $\mathbf{8 b}$ for $24 \mathrm{~h}$ and illuminated (one time or two times) or not at $540 \mathrm{~nm}$ during $20 \mathrm{~min}$. Quantification of spheroids size before 
and $48 \mathrm{~h}$ after by Imaris software were provided and presented as the growth percentages in bar graph. Volumes in $\mu m^{3}$ are presented in the table. *Statistically different from the volume before illumination $(p<0.05)$. All values are means \pm standard deviations of 3 independent experiments.

In vivo imaging and PDT effect. PDT efficiency on MDA-MB231 cells is crucial for the in vivo study. Indeed, the xenograft of zebrafish embryos with MCF-7 cells is not possible because cells made too many junctions between them, that avoids the injection with the ultra-fine and narrow needle such as this used for zebrafish injection. In contrast, MDA-MB-231 cells are well separated, they give less aggregates, which allowed to master the xenograft of human cells. The first step of the in vivo evaluation of theranostic potential of $\mathbf{8 b}$ was the investigation of its luminescence and its detection in the intravenous system of Casper zebrafish embryos, once injected in the caudal vein. Figure $10 \mathrm{~A}$ demonstrates a substantial fluorescence within the entire blood system of injected zebrafish embryos, suggesting a satisfactory dispersibility and bioavailability of $\mathbf{8 b}$. We also investigated the PDT activity on embryos xenografted with MDA-MB-231 stained with $\mathbf{8 b}$.

For this, $48 \mathrm{~h}$ post fertilization (hpf) zebrafish embryos were injected in the pericardial cavity with $10 \mathrm{~nL}$ containing 200 MDA-MB-231 cells previously stained with $\mathbf{8 b}(100 \mathrm{nM})$. The day after, they were anesthetized and submitted or not to $1 \mathrm{hv}$ excitation at $540 \mathrm{~nm}$ (10x objective, $40 \mathrm{~min}, 132 \mathrm{~J} \mathrm{~cm}^{-2}$ ). The safety of the conditions of excitation were previously verified on zebrafish embryos (data not shown). Figure 10B demonstrates that the injection of MDA-MB-231 cells stained with $\mathbf{8 b}$, induced a high and stable luminescent xenograft up to $24 \mathrm{~h}$ without any light excitation.

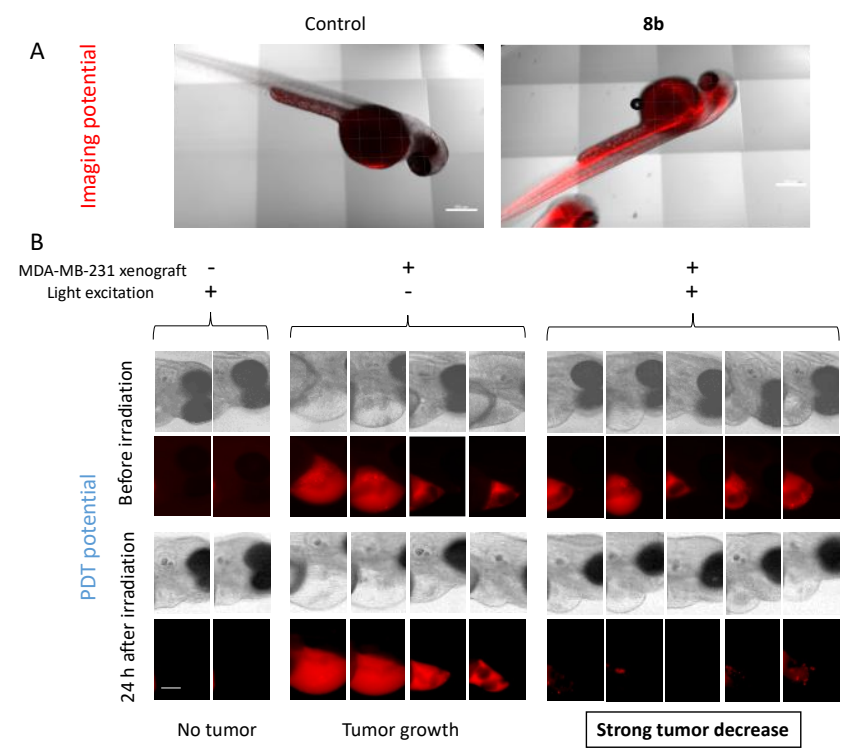

Figure 10. In vivo imaging and PDT potential of $\mathbf{8 b}$. (A) Representative Z-stack confocal microscopy pictures of fixed 48 hpf Casper zebrafish embryos injected $(n=14)$ or not $(n=10)$ with $10 \mathrm{~nL}$ of $\mathbf{8 b}$ at $0.5 \mu \mathrm{M}$ concentration Scale bar is $300 \mu \mathrm{m}$. (B) PDT potential study in $\mathbf{8 b}$ treated MDA-MB-231 xenograft in Casper zebrafish embryos submitted or not to light excitation during 40 min at $540 \mathrm{~nm}$. Control of non-injected embryos were included in the study. Scale bar is $150 \mu \mathrm{m}$.
In contrast, after PDT treatment we can note a very important decrease or almost complete disappearance of the red fluorescence, indicating tumor destruction and reflecting the strong potential of $\mathbf{8 b}$ for PDT application against cancer.

\section{CONCLUSION}

We described the versatile, efficient and rapid gram-scale synthesis of $\mathbf{8 a - b}$, the first $N$-alkyl analogs of induline $3 \mathrm{~B}$. Molecule $\mathbf{8 b}$ showed 2PA in the NIR, a strong fluorescence in the red range ( $\lambda_{\max }=637 \mathrm{~nm}$ with a quantum efficiency of 0.76 ) and the ability to generate $5 \%$ of singlet oxygen. Given the introduction of lipophilic substituents and appealing photophysical properties, $\mathbf{8} \mathbf{b}$ has been investigated as imaging and therapeutic agent (PDT). Under mono (514 nm) and biphotonic excitation (790 and $810 \mathrm{~nm}$ ), $\mathbf{8 b}$ is highly luminescent and target strongly the mitochondria. In addition, $\mathbf{8 b}$ is more efficiently and more quickly internalized by cancer cells than healthy fibroblasts, suggesting a better affinity for cancer cells. Remarkably, despite a relatively low singlet oxygen generation quantum yield, $\mathbf{8} \mathbf{b}$ induces a strong PDT effect on two different cancer cell lines (MCF-7 and MDA-MB231 cells) in 2D or 3D culture models. This therapeutic efficiency on xenografted zebrafish embryos yields an almost complete elimination of cancer cells that shall be added to the bright imaging properties of $\mathbf{8 b}$. Finally, the plain molecular structure of $\mathbf{8 b}$ based on a triamino-phenazinium core (no need of additional components), highlights the emergence of a novel and highly tunable minimalistic class of theranostic agents.

\section{EXPERIMENTAL SECTION}

Reagents. All reagents and solvents were purchased from Alfa-Aesar or Sigma-Aldrich and used as received. Column chromatography were performed using silica gel (60-120 mesh), alumina 90 basic (63-200 $\mu \mathrm{m}$, Beckmann grade III). Analytical thin layer chromatography (TLC) was performed on precoated silica gel-60 F254 (0.5 mm) aluminium plate. Filter aid was performed using Celite AW standard Supercel ${ }^{\circ}$ or Celite ${ }^{\circ}$ type 545 . Unless otherwise specified, the desired product was dried under vacuum ( $<10 \mathrm{mbar}$ ) over $5 \mathrm{~h}$ at room temperature. When heating was required, oil bathes were used.

Analytical methods and apparatus. ${ }^{1} \mathrm{H}$ NMR spectra were recorded at room temperature on a Bruker AC250, a Bruker AC500 or on a JEOL ECS400 spectrometers operating at 250, 500 and $400 \mathrm{MHz}$, respectively. ${ }^{13} \mathrm{C}$ NMR spectra were recorded at room temperature on a Bruker $A C 250$ or on a JEOL ECS400 spectrometers operating at 63 and $100 \mathrm{MHz}$, respectively. High-resolution mass spectrometry (HRMS) analysis was performed by the "Spectropole" of Aix-Marseille University.

Synthesis of 4. 2,4-Difluoronitrobenzene $3(6.5 \mathrm{~mL}, 0.059$ $\mathrm{mol})$, 1-octylamine $(40 \mathrm{~mL}, 0.243 \mathrm{~mol})$ and DIPEA $(18 \mathrm{~mL}, 0.101$ mol) were introduced into a pressure bomb which was then closed with a Teflon seal. The mixture was allowed to heat up to $145{ }^{\circ} \mathrm{C}$ for $3 \mathrm{~h}$. After cooling to room temperature, $15 \mathrm{~mL}$ ethanol were added. This suspension was triturated with ultrasound. The resulting solid in suspension was isolated by 
filtration, rinsed with hot water and dried under vacuum to afford the desired product 4 as a yellow powder $(21.6 \mathrm{~g}, 96 \%$ yield). TLC: $R_{f}=0.53\left(\mathrm{SiO}_{2} \mathrm{F60}\right.$, dichloromethane), $\mathrm{R}_{\mathrm{f}}=0.23$ $\left(\mathrm{SiO}_{2}\right.$, dichloromethane/cyclohexane, 7/3). ${ }^{1} \mathrm{H} \mathrm{NMR}(250 \mathrm{MHz}$, $\mathrm{CDCl}_{3}$ ): $\delta 8.52$ (br s, 1H), $7.99(\mathrm{~d}, J=9.3 \mathrm{~Hz}, 1 \mathrm{H}), 5.89$ (dd, $J=$ $9.3 \mathrm{~Hz}, J=2.3 \mathrm{~Hz}, 1 \mathrm{H}), 5.62(\mathrm{~d}, J=2.3 \mathrm{~Hz}, 1 \mathrm{H}), 4.52(\mathrm{br} \mathrm{s}, 1 \mathrm{H})$, $3.23-3.14(\mathrm{~m}, 4 \mathrm{H}), 1.75-1.62(\mathrm{~m}, 4 \mathrm{H}), 1.42-1.28(\mathrm{~m}, 2 \mathrm{H})$, $0.91-0.85(\mathrm{~m}, 6 \mathrm{H}) .{ }^{13} \mathrm{C} \mathrm{NMR}\left(63 \mathrm{MHz}, \mathrm{CDCl}_{3}\right): 154.4,148.6$, 129.2, 123.6, 104.7, 89.8, 43.3, 42.9, 31.8, 31.7, 29.3, 29.2, 29.1, 28.8, 27.1, 27.0, 22.6, 14.0. MS: ESI-MS: $\mathrm{m} / \mathrm{z}[\mathrm{M}+\mathrm{H}]^{+}$ 378.3 (100\%); [M-H] 376.3 (100\%), [M+CH $\mathrm{CH}_{3} \mathrm{COO}-436.3$ (48\%). Elemental analysis for $\mathrm{C}_{22} \mathrm{H}_{39} \mathrm{~N}_{3} \mathrm{O}_{2} \cdot 1 /{ }_{5} \cdot \mathrm{C}_{2} \mathrm{H}_{5} \mathrm{OH}$ : calcd. $\mathrm{C} 69.56, \mathrm{H}$ 10.48, N 10.86, O 9.10; found C 69.41, H 10.39, N 10.92.

Synthesis of 6. A solution of compound $4(628 \mathrm{mg}, 1.66$ $\mathrm{mmol}$ ) in THF ( $25 \mathrm{~mL}$ ) was hydrogenated (40 bars) overnight in the presence of $\mathrm{Pd} / \mathrm{C}$ ( $5 \mathrm{wt} . \%, 36 \mathrm{mg}, 0.02 \mathrm{mmol}, 1 \mathrm{~mol} \%$ ). After reducing the pressure, the solution was degassed under sonication for $5 \mathrm{~min}$. 1,5-difluoro-2,4-dinitrobenzene 5 (320 $\mathrm{mg}, 1.58 \mathrm{mmol}$ ) was added in the solution while stirring at 0 ${ }^{\circ} \mathrm{C}$. The solution was kept at this temperature for additional 10 min and the reaction completion was monitored by TLC. Then DIPEA (301 $\mu \mathrm{L}, 1.66 \mathrm{mmol}$ ) was added to neutralize the solution. $\mathrm{Pd} / \mathrm{C}$ was removed by filtration through a celite plug. The crude product was purified by flash chromatography on silica gel using dichloromethane / cyclohexane (1/1) as eluent to afford the desired product 6 as a red solid $(620 \mathrm{mg}, 84 \%$ yield). TLC: $\mathrm{R}_{\mathrm{f}}=0.29\left(\mathrm{SiO}_{2} \mathrm{F60}\right.$, dichloromethane/cyclohexane, 7/3). $1 \mathrm{H} \mathrm{NMR} \mathrm{(400} \mathrm{MHz,} \mathrm{CDCl} 3$ ): $\delta 9.31(\mathrm{~s}, 1 \mathrm{H}), 9.15$ (d, J = 7.7 $\mathrm{Hz}, 1 \mathrm{H}), 6.83(\mathrm{~d}, \mathrm{~J}=8.4 \mathrm{~Hz}, 1 \mathrm{H}), 6.53(\mathrm{~d}, \mathrm{~J}=13.4 \mathrm{~Hz}, 1 \mathrm{H}), 6.00$ (dd, J = 8.4, 2.3 Hz, 1H), $5.95(\mathrm{~d}, \mathrm{~J}=2.1 \mathrm{~Hz}, 1 \mathrm{H}), 3.77(\mathrm{br} \mathrm{s}, 1 \mathrm{H})$, 3.67 (br s, 1H), $3.13(\mathrm{t}, \mathrm{J}=7.2 \mathrm{~Hz}, 2 \mathrm{H}), 3.09-3.08(\mathrm{~m}, 2 \mathrm{H}), 1.65$ (quintet, $\mathrm{J}=7.2 \mathrm{~Hz}, 2 \mathrm{H}$ ), 1.56 (quintet, $\mathrm{J}=7.1 \mathrm{~Hz}, 2 \mathrm{H}$ ), $1.48-$ $1.18(\mathrm{~m}, 2 \mathrm{H}), 0.89(\mathrm{t}, \mathrm{J}=6.7 \mathrm{~Hz}, 3 \mathrm{H}), 0.87(\mathrm{t}, \mathrm{J}=6.7 \mathrm{~Hz}, 3 \mathrm{H})$. 13C NMR (100 MHz, CDCl 3 ): $\delta 159.9(d, J C-F=270.7 \mathrm{~Hz}), 150.5$, $150.3,150.2,145.1,128.5,127.7,127.7,127.6,126.9$ (d, JC-F = 10.2 Hz), 110.7, 103.9 (d, JC-F $=27.4 \mathrm{~Hz}$ ), 101.6, 95.1, 43.9, 43.4, 31.8, 31.81, 31.75, 29.5, 29.4, 29.30, 29.28, 29.25, 29.19, 27.2, 27.1, 22.65, 22.62, 14.09, 14.05. HRMS (ESI-TOF): $\mathrm{m} / \mathrm{z}$ $[\mathrm{M}+\mathrm{H}]+$ for $\mathrm{C}_{28} \mathrm{H}_{43} \mathrm{FN}_{5} \mathrm{O}_{4}$ : calcd. 532.3294, found 532.3281, err. $<2$ ppm.

Synthesis of 7a. A solution of compound $4(628 \mathrm{mg}, 1.66$ $\mathrm{mmol}$ ) in THF (25 mL) was hydrogenated (40 bars) overnight in presence of $\mathrm{Pd} / \mathrm{C}$ (5 wt.\%, $36 \mathrm{mg}, 1 \mathrm{~mol} \%$ ). After reducing the pressure, the solution was degassed under sonication for 5 min, then cooled to $0^{\circ} \mathrm{C}$ an ice-bath, and 1,5-difluoro-2,4dinitrobenzene $(320 \mathrm{mg}, 1.58 \mathrm{mmol}$ ) was added in the solution while stirring. The reaction was kept at $0{ }^{\circ} \mathrm{C}$ for $10 \mathrm{~min}$. Then $1-$ octylamine ( $286 \mu \mathrm{L}, 1.93 \mathrm{mmol})$ and DIPEA ( $289 \mu \mathrm{L}, 1.66 \mathrm{mmol})$ were added. The mixture was stirred at room temperature for 3 days. After a filtration through a Celite plug and a concentration, the crude product was purified by flash chromatography on silica gel using dichloromethane/cyclohexane (50/50 to 55/45) as eluent to afford the desired product $7 \mathrm{a}$ as a red solid $(498 \mathrm{mg}, 49 \%$ yield). TLC: $\mathrm{R}_{\mathrm{f}}=0.27\left(\mathrm{SiO}_{2} \mathrm{F60}\right.$, dichloromethane/cyclohexane, 7/3). $\left.{ }^{1} \mathrm{H} \mathrm{NMR} \mathrm{(400} \mathrm{MHz,} \mathrm{CDCl}_{3}\right): \delta 9.27$ (s, 1H), 9.12 (br s, 1H), $8.21(\mathrm{brt}, J=4.8 \mathrm{~Hz}, 1 \mathrm{H}), 6.87(\mathrm{~d}, J=8.3 \mathrm{~Hz}, 1 \mathrm{H}), 6.00(\mathrm{dd}, J=$ 8.3, 2.2 Hz, 1H), 5.96 (d, J = 2.2 Hz, 1H), 5.69 (s, 1H), 3.77 (br s,
$1 \mathrm{H}), 3.68(\mathrm{br} \mathrm{s}, 1 \mathrm{H}), 3.13(\mathrm{t}, J=7.2 \mathrm{~Hz}, 2 \mathrm{H}), 3.13-3.05(\mathrm{~m}, 2 \mathrm{H})$, $3.00(\mathrm{q}, J=6.1 \mathrm{~Hz}, 2 \mathrm{H}), 1.68-1.52(\mathrm{~m}, 6 \mathrm{H}), 1.45-1.23(\mathrm{~m}$, $30 \mathrm{H}), 0.90-0.84(\mathrm{~m}, 9 \mathrm{H}) .{ }^{13} \mathrm{C}$ NMR $\left(100 \mathrm{MHz} \mathrm{CDCl}_{3}\right): \delta 149.5$, 149.0, 148.4, 145.2, 129.4, 128.6, 124.8, 124.3, 112.0, 101.5, 95.2, 93.0, 44.1, 43.5, 43.1, 31.8, 31.8, 31.7, 29.6, 29.43, 29.37, 29.32, 29.24, 29.22, 29.19, 29.1, 28.2, 27.2, 27.1, 26.9, 22.63, 22.61, 22.60, 14.07, 14.06, 14.04. HRMS (ESI-TOF): $\mathrm{m} / z$ [M+1] for $\mathrm{C}_{36} \mathrm{H}_{60} \mathrm{~N}_{6} \mathrm{O}_{4}$ l: calcd. 767.3726, found 767.3725, err. $<2$ ppm.

Synthesis of 7b. A solution of compound 4 ( $1 \mathrm{~g}, 2.65 \mathrm{mmol})$ in THF (35 mL) was hydrogenated (40 bars) overnight in presence of $\mathrm{Pd} / \mathrm{C}$ ( $5 \mathrm{wt} . \%, 56 \mathrm{mg}, 1 \mathrm{~mol} \%$ ). After reducing the pressure, the solution was degassed under sonication for 5 $\min$, then cooled to $0^{\circ} \mathrm{C}$ an ice-bath, and 1,5-difluoro-2,4dinitrobenzene ( $514 \mathrm{mg}, 2.52 \mathrm{mmol}$ ) was added in the solution while stirring. The reaction was kept at $0{ }^{\circ} \mathrm{C}$ for $10 \mathrm{~min}$. Then tert-butylamine $(1.17 \mathrm{~mL}, 11.12 \mathrm{mmol})$ and DIPEA ( $969 \mu \mathrm{L}, 5.56$ $\mathrm{mmol}$ ) were added. The mixture was stirred at room temperature for 4 days. After filtration through a Celite plug via dichloromethane and evaporation of the solution, the crude product was purified by flash chromatography on silica gel using dichloromethane / cyclohexane (1/1 to 6/4) as eluent to afford the desired product $7 \mathrm{~b}$ as a red solid $(1.33 \mathrm{mg}, 91 \%$ yield). TLC: $\mathrm{R}_{\mathrm{f}}=0.25\left(\mathrm{SiO}_{2} \mathrm{F60}\right.$, dichloromethane/cyclohexane, 7/3). ${ }^{1} \mathrm{H}$ NMR (400 MHz, $\left.\mathrm{CDCl}_{3}\right): \delta 9.26(\mathrm{~s}, 1 \mathrm{H}), 9.00(\mathrm{br} \mathrm{s}, 1 \mathrm{H})$, 8.40 (br s, $1 \mathrm{H}), 6.86(\mathrm{~d}, J=8.3 \mathrm{~Hz}, 1 \mathrm{H}), 5.99(\mathrm{dd}, J=8.3,2.4 \mathrm{~Hz}$, $1 \mathrm{H}), 5.95(\mathrm{~d}, J=2.4 \mathrm{~Hz}, 1 \mathrm{H}), 5.91(\mathrm{~s}, 1 \mathrm{H}), 3.81(\mathrm{br} \mathrm{s}, 1 \mathrm{H}), 3.66$ (br s, $1 \mathrm{H}), 3.12(\mathrm{t}, J=7.1 \mathrm{~Hz}, 2 \mathrm{H}), 3.07-3.03(\mathrm{~m}, 2 \mathrm{H}), 1.66-$ $1.59(\mathrm{~m}, 2 \mathrm{H}), 1.56-1.50(\mathrm{~m}, 2 \mathrm{H}), 1.44-1.22(\mathrm{~m}, 29 \mathrm{H}), 0.89(\mathrm{t}$, $6.9 \mathrm{~Hz}, 3 \mathrm{H}), 0.86(\mathrm{t}, 6.9 \mathrm{~Hz}, 3 \mathrm{H}) .{ }^{13} \mathrm{C} N M R\left(100 \mathrm{MHz} \mathrm{CDCl}_{3}\right): \delta$ 149.7, 148.4, 147.4, 145.4, 129.5, 129.0, 125.5, 124.0, 112.1, $101.5,95.6,95.1,52.0,44.1,43.5,31.82,31.75,29.52,29.46$, 29.41, 29.30, 29.27, 29.20, 29.0, 27.2, 27.1, 22.65, 22.61, 14.09, 14.07. HRMS (ESI-TOF): $\mathrm{m} / 2[\mathrm{M}+\mathrm{H}]^{+}$for $\mathrm{C}_{32} \mathrm{H}_{53} \mathrm{~N}_{6} \mathrm{O}_{4}$ calcd. 585.4123, found 585.4123, err. < 1 ppm.

Synthesis of $8 \mathrm{a}$. A solution of 7a $(200 \mathrm{mg}, 0.31 \mathrm{mmol})$ in methanol $(40 \mathrm{~mL}$ ) was hydrogenated (40 bars) overnight in presence of $\mathrm{Pd} / \mathrm{C}(5 \mathrm{wt} . \%)$ and $\mathrm{HCl}(12 \mathrm{M}, 0.1 \mathrm{~mL})$. Then the mixture was stirred under air for $24 \mathrm{~h}$. $\mathrm{Pd} / \mathrm{C}$ was removed by filtration through a celite plug. After removal of the solvent under reduced pressure, the resulting solid was taken up with dichloromethane $(80 \mathrm{~mL})$, washed with an aqueous $\mathrm{HPF}_{6}$ solution ( $1 \mathrm{wt} . \%$ in water, $2 \times 50 \mathrm{~mL}$ ) then distilled water (50 $\mathrm{mL}$ ) and finally concentrated. The residue was purified flash chromatography on standard alumina 90 using dichloromethane/cyclohexane (100/0 to 99/1) as eluent to afford the desired product $8 \mathrm{a}$ as a red solid $(192 \mathrm{mg}, 87 \%$ yield). ${ }^{1} \mathrm{H}$ NMR (400 MHz, $\left.\mathrm{CD}_{3} \mathrm{CN}\right): \delta 7.78(\mathrm{~d}, J=9.2 \mathrm{~Hz}, 1 \mathrm{H})$, $7.19(\mathrm{dd}, J=9.2 \mathrm{~Hz}, 1.7 \mathrm{~Hz}, 1 \mathrm{H}), 6.96(\mathrm{~s}, 1 \mathrm{H}), 6.89(\mathrm{~s}, 1 \mathrm{H}), 6.52$ (d, $J=1.7 \mathrm{~Hz}, 1 \mathrm{H}), 6.24$ (brt, $J=5.2 \mathrm{~Hz}, 1 \mathrm{H}), 6.18$ (br s, 2H), 4.78 (br s, 1H), $4.54(\mathrm{t}, J=8.1 \mathrm{~Hz}, 2 \mathrm{H}), 3.34(\mathrm{td}, J=6.7 \mathrm{~Hz}, 6.0 \mathrm{~Hz}$, $2 \mathrm{H}), 3.28(\mathrm{td}, J=6.7 \mathrm{~Hz}, 5.2 \mathrm{~Hz}, 2 \mathrm{H}), 1.79-1.67(\mathrm{~m}, 4 \mathrm{H}), 1.64-$ $1.56(\mathrm{~m}, 2 \mathrm{H}), 1.51-1.30(\mathrm{~m}, 30 \mathrm{H}), 0.91-0.88(\mathrm{~m}, 9 \mathrm{H}) .{ }^{13} \mathrm{C}$ NMR (100 MHz, DMSO-d6): $\delta=154.1,150.7,140.1,139.8,137.5$, 133.9, 133.0, 131.4, 121.8, 105.3, 94.3, 90.2, 48.9, 44.8, 44.1, $32.52,32.46,30.05,30.02,29.97,29.95,29.10,29.06,27.9$, 27.7, 27.4, 27.1, 23.3, 14.3. HRMS (ESI-TOF): $m / z[M+H]^{+}$for $\mathrm{C}_{36} \mathrm{H}_{60} \mathrm{~N}_{5}$ : calcd. 562.4843, found 562.4855, err. < 3 ppm. 
Synthesis of $\mathbf{8 b}$. A solution of compound $8 \mathrm{a}(1 \mathrm{~g}, 1.71 \mathrm{mmol})$ in methanol (60 mL) was hydrogenated (20 bars) in the presence of $\mathrm{Pd} / \mathrm{C}(5 \mathrm{wt} . \%)$ and $\mathrm{HCl}(12 \mathrm{M}, 0.5 \mathrm{~mL})$ for $6 \mathrm{~h}$. Then the mixture was stirred under air for $16 \mathrm{~h}$. Pd/C was removed by filtration through a Celite (AW) plug which was rinsed multiple times with methanol and dichloromethane. After removal of the solvent under reduced pressure, the resulting solid was taken up with dichloromethane, washed with an aqueous $\mathrm{HPF}_{6}$ solution ( $5 \mathrm{wt} . \%$ in water, $2 \times 60 \mathrm{~mL}$ ) and distilled water $(60 \mathrm{~mL})$. The organic layer was dried over anhydrous $\mathrm{Na}_{2} \mathrm{SO}_{4}$, filtered and evaporated under reduced pressure. The obtained residue was finally precipitated in pentane and filtered to afford the desired product $\mathbf{8 b}$ as a red solid (1.05 $\mathrm{g}$, $95 \%$ yield). ${ }^{1} \mathrm{H}$ NMR (250 MHz, $\mathrm{CD}_{3} \mathrm{CN}$, diluted): $\delta 7.82$ (d, $J=$ $9.3 \mathrm{~Hz}, 1 \mathrm{H}), 7.24-7.20(\mathrm{~m}, 2 \mathrm{H}), 6.99(\mathrm{~s}, 1 \mathrm{H}), 6.57(\mathrm{~d}, J=1.8 \mathrm{~Hz}$, $1 \mathrm{H}), 6.28-6.20(\mathrm{br} \mathrm{m}, 3 \mathrm{H}), 4.57$ (d, J = 8 Hz, 2H), 4.37 (br s, 1H), $3.37(\mathrm{td}, J=7.0 \mathrm{~Hz}, J=6.2 \mathrm{~Hz}, 2 \mathrm{H}), 1.75-1.55(\mathrm{~m}, 4 \mathrm{H}), 1.52(\mathrm{~s}$, $9 \mathrm{H}), 1.46-1.31(\mathrm{~m}, 20 \mathrm{H}), 0.92-0.87(\mathrm{~m}, 6 \mathrm{H}) .{ }^{1} \mathrm{H}$ NMR $(250$ $\mathrm{MHz}, \mathrm{CD}_{3} \mathrm{CN}$, concentrated): $\delta 7.76(\mathrm{~d}, J=9.3 \mathrm{~Hz}, 1 \mathrm{H}), 7.20-$ $7.15(\mathrm{~m}, 2 \mathrm{H}), 6.96(\mathrm{~s}, 1 \mathrm{H}), 6.49(\mathrm{~d}, J=1.8 \mathrm{~Hz}, 1 \mathrm{H}), 6.34-6.29$ (br m, 3H), $4.50(\mathrm{t}, \mathrm{J}=8 \mathrm{~Hz}, 2 \mathrm{H}), 3.41-3.33(\mathrm{~m}, 2 \mathrm{H}), 1.76-1.30$ $(\mathrm{m}, 33 \mathrm{H}), 0.91-0.86(\mathrm{~m}, 6 \mathrm{H}) .{ }^{13} \mathrm{C} N M R\left(63 \mathrm{MHz}, \mathrm{CD}_{3} \mathrm{CN}\right.$, concentrated):154.3, 152.4, 139.3, 137.8, 137.6, 134.1, 133.2, 131.3,121.7, 109.6, 94.7, 90.3, 53.1, 48.8, 44.2, 32.53, 32.48, $30.03,29.98,29.95,29.16,29.10,27.8,27.5,27.2,23.33$, 23.32, 14.34, 14.33. HRMS (ESI-TOF): $m / z[M+H]^{+}$for $\mathrm{C}_{32} \mathrm{H}_{52} \mathrm{~N}_{5}$ : calcd. 506.4217, found 506.4220, err. $<1$ ppm.

Crystallography. Suitable crystals for compound 8b were obtained from slow evaporation from $\mathrm{MeOH}$ and $\mathrm{CH}_{3} \mathrm{CN}$, respectively. They were mounted and investigated as previously reported. ${ }^{51}$ For compound $\mathbf{8 b}$, the terminal part of one octylamine moiety was found to be disordered and refined on two sites with occupation factors equal to 0.5 . All $\mathrm{H}$-atoms except those of the disordered octylamine were found experimentally.

Electronic absorption and fluorescence. UV-vis absorption spectra were recorded on a VARIAN CARY 50 SCAN spectrophotometer at room temperature. Fluorescence spectra and singlet oxygen emission were recorded as reported. ${ }^{52}$ Fluorescence quantum yields have been measured relative to Rhodamine $\mathrm{B}(0.70$ in $\mathrm{MeOH})$ for compound $\mathbf{8 b}$ or tetraphenylporphyrin (0.15 in $\mathrm{MeCN}$ ) for compound 11.53 Singlet oxygen quantum yield has been measured relative to tetraphenylporphyrin (0.80 in $\mathrm{MeCN}$ ).

Two-photon absorption. The measurements were carried out according to the reported conditions. ${ }^{54}$

Theoretical calculations. The optimized geometries and frequencies of the singlet ground state $\left(S_{0}\right)$ of 8-11 have been obtained at the density functional theory level using the M06$2 \mathrm{X}$ exchange-correlation functional ${ }^{55}$ combined with the 6$31 \mathrm{G}(\mathrm{d})$ basis set. The same functional was used to the subsequent Time-Dependent DFT (TD-DFT) calculations, using the $6-311+G(2 d, p)$ basis set, a choice justified by previous benchmarks. ${ }^{56}$ To speed-up the calculations, we have replaced the alkyl chains by methyl substituents, which is unlikely to affect significantly the optical properties (hence $\mathbf{8 a}=\mathbf{8 b}$ in the calculations. The aromaticity has been determined by both the
NICS(0) and NICS(1) criteria (nucleus-independent chemical shift) determined at the centers of each rings. ${ }^{57}$ All these DFT and TD-DFT calculations use the polarizable continuum model (PCM) to account for solvent effects, applying the linearresponse solvent approach for the TD-DFT part. These calculations have been performed with the Gaussian suite of programs, $^{58}$ applying default procedures and algorithms except for tightened SCF $\left(10^{-10}\right.$ a.u.) and force $\left(10^{-5}\right.$ a.u.) convergence thresholds. As it is well-known that cyanine-like dyes are challenging for TD-DFT, we have performed gas phase SOS-CIS(D)/6-311+G(2d,p) calculations ${ }^{59}$ on the $S_{0}$ geometries using the $\mathrm{Q}$-Chem 4.2 code. $^{60}$ With this approach, the theoretical best estimate of the vertical transition energies can be determined as $\Delta E=\Delta E^{\mathrm{SOS}-\mathrm{CIS}(\mathrm{D})}$ (gas) + $\Delta E^{\mathrm{TD}-\mathrm{DFT}}(\mathrm{PCM})-\Delta E^{\mathrm{TD}-\mathrm{DFT}}$ (gas).

Cell culture. Human breast cancer cells (MCF-7 and MDAMB-231), and healthy fibroblasts were purchased from ATCC (American Type Culture Collection, Manassas, VA). MCF-7 cells were cultured in Dulbecco's Modified Eagle's Medium (DMEM)-F12, supplemented with $10 \%$ fetal bovine serum (FBS) and $1 \%$ penicillin / streptomycin (P/S). MDA-MB-231 cells were cultured in DMEM supplemented with $10 \%$ FBS and $50 \mu \mathrm{g} \mathrm{mL} \mathrm{m}^{-1}$ gentamycin. Healthy fibroblasts were maintained in Roswell Park Memorial Institute medium (RPMI -1640) supplemented with $10 \% \mathrm{FBS}$ and $1 \% \mathrm{P} / \mathrm{S}$. All cells were maintained in a humidified atmosphere, at $37^{\circ} \mathrm{C}$ with $5 \% \mathrm{CO}_{2}$.

Flow cytometry. Cancer cells and healthy fibroblasts were incubated for $24 \mathrm{~h}$ or not with $0.05,0.1,0.5,1$ or $5 \mathrm{nM}$ of $\mathbf{8 b}$ for the dose-response study. In parallel, kinetic studies were performed on cancer cells and healthy fibroblasts treated or not with $0.5 \mathrm{nM}$ of $\mathbf{8 b}$ for $1,3,6$ or $24 \mathrm{~h}$. At the end of incubation time, all cells were washed twice with cold Phosphate Buffered Saline (PBS), harvested and centrifuged (1300 rpm, $5 \mathrm{~min}$ ). Cell were re-suspended in complete PBS (enriched with $\mathrm{CaCl}^{2+}$ and $\mathrm{MgCl}^{2+}$ ) and stained by propidium iodide ( $1 \mu \mathrm{g} \cdot \mathrm{mL}^{-1}$ ) (Sigma-Aldrich Chimie, Lyon, France), as an indicator of cell death. Determination of living cells containing 8b was done by FACS CytoFlex Flow Cytometer (Beckman Coulter, France) with a minimum of 10000 living cells collected.

Confocal microscopy imaging. MCF-7 or MDA-MB-231 cells were seeded into bottom glass dishes (World Precision Instrument, Stevenage, UK) at a density of $10^{6}$ cells. $\mathrm{cm}^{-2}$. Then, $24 \mathrm{~h}$ after seeding, cancer cells were washed once and incubated with $1 \mathrm{~mL}$ of fresh medium containing $\mathbf{8 b}$ at a concentration of 0.1 or $0.5 \mu \mathrm{M}$ for $16 \mathrm{~h}$. Fifteen minutes before the end of incubation, cells were incubated with: (i) Hoechst 33342 (10 $\mu \mathrm{g} \mathrm{mL}^{-1}$, Invitrogen) for nuclear staining; (ii) MitoTracker Green FM (100 nM, Thermo Fisher) for mitochondria staining; (iii) CellMask Green 522/535 nm (5 $\mu \mathrm{g} \cdot \mathrm{mL}^{-1}$, Thermo Fisher) for membrane cell staining. Two hours before the end of incubation, cells were incubated with LysoTracker Green DND-26 (1 $\mu \mathrm{M}$, Thermo Fisher) for endolysosomal vesicles staining. Just before observation, cells were washed several times with culture media to remove excess of staining molecules. Cells were then visualized thanks to LSM 780 LIVE confocal microscope (Carl Zeiss, Le Pecq, 
France), at $514 \mathrm{~nm}$ (continuous laser), $790 \mathrm{~nm}$ or $810 \mathrm{~nm}$ (pulsed laser) using a high magnification (63x/1.4 OIL DIC PlanApo).

One-photon excited photodynamic therapy in 2D culture model. MCF-7 or MDA-MB-231 cells were seeded into a 96 multi-well at 1000 cells/well in $100 \mu \mathrm{L}$ of culture medium, and allowed to grow for $24 \mathrm{~h}$. Cells were then treated or not with $\mathbf{8 b}$ at increasing concentrations $(1,10$ or $100 \mathrm{nM})$ for $5 \mathrm{~h}$. After treatment, cancer cells were irradiated or not at $540 \mathrm{~nm}$ during $20 \min \left(46 \mathrm{~J} \mathrm{~cm}^{-2}\right)$. Two days after irradiation, the MTT assay was performed to evaluate the cell viability. For that, cells were treated for $4 \mathrm{~h}$ with MTT (3-(4,5-dimethylthiazol-2-yl)2,5-diphenyltetrazolium bromide; Promega) in media. Then, $\mathrm{MTT} /$ media solution was removed and crystals thus formed were dissolved in EtOH/DMSO (1:1). As manufacturer recommendations, absorbance was read at $540 \mathrm{~nm}$.

Study of PDT efficiency in 3D models. MDA-MB-231 and MCF-7 cells were seeded in their respective culture medium, in 96-well plate glass bottom half-area, previously coated with $1 \%$ agarose, at a density of 500 cells per $50 \mu \mathrm{L}$, then were centrifuged at $331 \mathrm{~g}$ for $4 \mathrm{~min}$. After $24 \mathrm{~h}$, collagen was added in each well to reach a final concentration of $3 \mu \mathrm{g} \mathrm{mL}^{-1}$, and then cells were centrifuged at $138 \mathrm{~g}$ for $4 \mathrm{~min}$ and were placed in the incubator. Four days later, spheroids were treated with $1 \mu \mathrm{M}$ of $\mathbf{8 b}$ for $24 \mathrm{~h}$. Before light irradiation, spheroids were exposed to Z-stack imaging using spinning disk dragonfly microscopy at $\lambda_{\mathrm{ex}}=561 \mathrm{~nm}$ and $\lambda_{\mathrm{em}}=620 \mathrm{~nm}, 10 x$ objective, step size $=5 \mu \mathrm{m}$. In case of 3D MCF-7 cells, they were exposed to light irradiation for $20 \mathrm{~min}$ (objective lens $4 \mathrm{x}, \lambda_{\mathrm{ex}}=540 \mathrm{~nm}$, $46 \mathrm{~J} \mathrm{~cm}^{-2}$ ) and exposed to Z-stack imaging $48 \mathrm{~h}$ after irradiation. In contrast, 3D MDA-MB-231 cells were exposed to two different light irradiation conditions; the first condition was similar to 3D MCF-7 cells; the second one was exposing the spheroids to light irradiation for $20 \mathrm{~min}$, then $24 \mathrm{~h}$ after a second identical irradiation was applied. Obtained Z-stack images were processed using microscopy image analysis Imaris software (Bitplane, Oxford instruments, UK) to reconstruct a 3D model and calculating the obtained volumes. Data were presented as a growth volume percentage (\%) calculated according to the following equation (volume of spheroid after/ volume of spheroid before $\left.{ }^{*} 100\right)$.

Imaging on Zebrafish embryos. Casper zebrafish embryos (see breeding conditions in $\mathrm{SI}$ ) at 48 hours post fertilization (hpf) were anesthetized with tricaine solution for $10 \mathrm{~min}$. Casper embryos were injected $(n=14)$ or not $(n=10)$ with 10 $\mathrm{nL}$ of $\mathbf{8 b}$ at $0.5 \mu \mathrm{M}$ concentration in the caudal vein. Then zebrafishes were fixed with $4 \%$ paraformaldehyde solution (PFA) and Z-stack confocal microscopy pictures were performed. Images were acquired at an excitation wavelength of $561 \mathrm{~nm}$, slow speed scan of $2024 \times 2024$ pixels and $40 \mathrm{Z}$ stacks. The images were processed using Imaris software.

Study of PDT efficiency in Zebrafish embryos. MDA-MB-231 cells were seeded in Nunc EasYFlask $75 \mathrm{~cm}^{2} .24 \mathrm{~h}$ after seeding, cells were treated with $100 \mathrm{nM}$ of $\mathbf{8 b}$ for $24 \mathrm{~h}$. After incubation, cells were washed trice with phosphate buffered saline (PBS) then were trypsinized and suspended in culture medium. Cells were counted, centrifuged and then they were suspended in the required volume of PBS containing $10 \%$ FBS to have a solution of $2 \times 10^{7}$ cells per $1 \mathrm{~mL}$. The solution was kept in ice until injection. Casper embryos at $48 \mathrm{hpf}$ were used. Embryos were anesthetized with tricaine solution $10 \mathrm{~min}$ prior to injection. Then, embryos were placed on agar mold for the microinjection of MDA-MB-231 cells previously incubated with $8 \mathbf{b}(100 \mathrm{nM})$. Each embryo received 2 pulses of $5 \mathrm{~nL}$ cell suspension to get $\sim 200-300$ injected cells per embryo in the pericardial cavity. Non-injected Casper embryos were used as a control. After injection, embryos were placed in $100 \mathrm{~mm} \times 20$ $\mathrm{mm}$ petri-dish containing $30 \mathrm{~mL}$ of water at $28^{\circ} \mathrm{C} .24 \mathrm{~h}$ after injection, embryos were imaged using loupe Olympus microscopy at $\lambda_{\mathrm{ex}}=545$ and $\lambda_{\mathrm{em}}=610 \mathrm{~nm}$ for $\mathbf{8 b}$ detection, bright field images were also acquired. Then, each embryo was placed in a well in 96 well plate with $200 \mu \mathrm{L}$ of water. Embryos were divided into two groups: no light irradiation group and light irradiation group. Each embryo in the light irradiation group was exposed to light for 40 min (Objective lens 10x, $\lambda_{\text {ex }}$ $=540 \mathrm{~nm}, 132 \mathrm{~J}$ trypsinized $\mathrm{cm}^{-2}$ ). Non-injected group were also exposed to light irradiation. Twenty-four hours after irradiation, embryos were imaged again.

\section{ASSOCIATED CONTENT}

\section{Supporting Information}

(Electronic Supplementary Information (ESI) available: ${ }^{1} \mathrm{H},{ }^{13} \mathrm{C}$ NMR spectra, HRMS spectra, additional crystallographic, optical and theoretical data and details. CCDC 2010074 contains the supplementary crystallographic data for this paper (compound 8a). The Supporting Information is available free of charge on the ACS Publications website.

\section{AUTHOR INFORMATION}

\section{Corresponding Authors}

Magali Gary-Bobo - IBMM, Univ Montpellier, CNRS, ENSCM, Montpellier, France; ORCID: 0000-0001-9641-212X; magali.garybobo@inserm.fr

Denis Jacquemin - Université de Nantes, CNRS, CEISAM, UMR 6230, Nantes, F-44000 France; ORCID: 0000-0002-4217-0708; Email: Denis.Jacquemin@univ-nantes.fr

Olivier Siri-Aix Marseille Univ, CNRS, CINaM, UMR 7325, Campus de Luminy, 13288 Marseille cedex 09, France; ORCID: 0000-0001-9747-3813; Email: olivier.siri@univ-amu.fr

\section{Authors}

Zhongrui Chen - Aix Marseille Univ, CNRS, CINaM, UMR 7325, Campus de Luminy, 13288 Marseille cedex 09, France Simon Pascal - Aix Marseille Univ, CNRS, CINaM, UMR 7325, Campus de Luminy, 13288 Marseille cedex 09, France; ORCID: 0000-0001-8387-494X

Morgane Daurat - NanoMedSyn, 15 av Charles Flahault, 34093 Montpellier, Cedex 5 France; ORCID: 0000-0001-6448-3775

Laure Lichon - IBMM, Univ Montpellier, CNRS, ENSCM, Montpellier, France;

Christophe Nguyen - IBMM, Univ Montpellier, CNRS, ENSCM, Montpellier, France; ORCID: 0000-0003-4539-1677

Anastasia Godefroy - NanoMedSyn, 15 av Charles Flahault, 34093 Montpellier, Cedex 5 France;

Denis Durand - IBMM, Univ Montpellier, CNRS, ENSCM, Montpellier, France; 
Lamiaa M. A. Ali - IBMM, Univ Montpellier, CNRS, ENSCM, Montpellier, France; Department of Biochemistry, Medical Research Institute, University of Alexandria, 21561 Alexandria, Egypt; ORCID: 0000-0003-1176-5335

Nadir Bettache - IBMM, Univ Montpellier, CNRS, ENSCM, Montpellier, France; ORCID: 0000-0001-5426-7024

Philippe Arnoux - Université de Lorraine, CNRTS, LRGP, UMR 7274, 54000 Nancy, France;

Jean-François Longevial - Aix Marseille Univ, CNRS, CINaM, UMR 7325, Campus de Luminy, 13288 Marseille cedex 09, France; ORCID: 0000-0002-7736-3673

Anthony D'Aléo - Aix Marseille Univ, CNRS, CINaM, UMR 7325, Campus de Luminy, 13288 Marseille cedex 09, France; Gabriel Marchand - Université de Nantes, CNRS, CEISAM, UMR 6230, Nantes, F-44000 France; ORCID: 0000-0002-3572-9091

\section{ACKNOWLEDGMENT}

This work was supported by the Centre National de la Recherche Scientifique, the Ministère de la Recherche et des Nouvelles Technologies (France). O.S. thanks CNRS Innovation for the attribution of a grant to J.-F. L.. This research used resources of (i) the GENCI-CINES/ IDRIS; (ii) Centre de Calcul Intensif des Pays de Loire; (iii) a local Troy cluster and (iv) HPC resources from ArronaxPlus (Grant No. ANR-11-EQPX-0004 funded by the French National Agency for Research).

\section{REFERENCES}

(1) Yoon, H. Y.; Jeon, S.; You, D. G.; Park, J. H.; Kwon, I. C.; Koo, H.; Kim, K. Inorganic Nanoparticles for Image-Guided Therapy. Bioconjugate Chem. 2017, 28, 124-134.

(2) Zhang, J.; Ning, L.; Huang, J.; Zhang, C.; Pu, K. Activatable Molecular Agents for Cancer Theranostics. Chem. Sci. 2020, 11, 618630.

(3) Crawley, N.; Thompson, M.; Romaschin, A. Theranostics in the Growing Field of Personalized Medicine: An Analytical Chemistry Perspective. Anal. Chem. 2014, 86, 130-160.

(4) Terreno, E.; Uggeri, F.; Aime, S. Image Guided Therapy: The Advent of Theranostic Agents. J. Controlled Release 2012, 161, 328337.

(5) Kelkar, S. S.; Reineke, T. M. Theranostics: Combining Imaging and Therapy. Bioconjugate Chem. 2011, 22, 1879.

(6) Blau, R.; Epshtein, Y.; Pisarevsky, E.; Tiram, G.; Israeli Dangoor, S.; Yeini, E.; Krivitsky, A.; Eldar-Boock, A.; Ben-Shushan, D.; Gibori, H.; Scomparin, A.; Green, O.; Ben-Nun, Y.; Merquiol, E.; Doron, H.; Blum, G.; Erez, N.; Grossman, R.; Ram, Z.; Shabat, D.; Satchi-Fainaro, R. Image-Guided Surgery Using Near-Infrared Turn-ON Fluorescent Nanoprobes for Precise Detection of Tumor Margins. Theranostics 2018, 8, 3437-3460.

(7) Jenni, S.; Sour, A. Molecular Theranostic Agents for Photodynamic Therapy (PDT) and Magnetic Resonance Imaging (MRI). Inorganics 2019, 7, 10.

(8) Perry, H. L.; Botnar, R. M.; Wilton-Ely, J. D. E. T. Gold Nanomaterials Functionalised with Gadolinium Chelates and their Application in Multimodal Imaging and Therapy. Chem. Commun. 2020, 56, 4037-4046.

(9) Muthu, M. S.; Leong, D. T.; Mei, L.; Feng, S.-S. Nanotheranostics - Application and Further Development of Nanomedicine Strategies for Advanced Theranostics. Theranostics 2014, 4, 660-677.

(10) Yang, M.; Huang, J.; Fan, J.; Du, J.; Pu, K.; Peng, X. Chemiluminescence for Bioimaging and Therapeutics: Recent Advances and Challenges. Chem. Soc. Rev. 2020, 49, 6800-6815.

(11) Kunjachan, S.; Ehling, J.; Storm, G.; Kiessling, F.; Lammers, T. Noninvasive Imaging of Nanomedicines and Nanotheranostics: Principles, Progress, and Prospects. Chem. Rev. 2015, 115, 1090710937.
(12) Chen, G.; Roy, I.; Yang, C.; Prasad, P. N. Nanochemistry and Nanomedicine for Nanoparticle-based Diagnostics and Therapy. Chem. Rev. 2016, 116, 2826-2885.

(13) Wang, J.; Zhu, X.; Zhang, J.; Wang, H.; Liu, G.; Bu, Y.; Yu, J.; Tian, Y.; Zhou H. AlE-Based Theranostic Agent: In Situ Tracking Mitophagy Prior to Late Apoptosis To Guide the Photodynamic Therapy. ACS Appl. Mater. Interfaces 2020, 12, 1988-1996.

(14) Björnmalm, M.; Thurecht, K. J.; Michael, M.; Scott, A. M.; Caruso, F. Bridging Bio-Nano Science and Cancer Nanomedicine. ACS Nano 2017, 11, 9594-9613.

(15) Gauger, A. J.; Hershberger, K. K.; Bronstein, L. M. Theranostics Based on Magnetic Nanoparticles and Polymers: Intelligent Design for Efficient Diagnostics and Therapy. Front. Chem. 2020, 8, 561.

(16) Fan, Z.; Fu, P. P.; Yu, H.; Ray, P. C. Theranostic Nanomedicine for Cancer Detection and Treatment. J. Food Drug Anal. 2014, 22, 317.

(17) Kumar, R.; Shin, W. S.; Sunwoo, K.; Kim, W. Y.; Koo, S.; Bhuniya, S.; Kim, J. S. Small Conjugate-Based Theranostic Agents: an Encouraging Approach for Cancer Therapy. Chem. Soc. Rev. 2015, 44, 6670- 6683

(18) Hu, F.; Qi, G.; Kenry, Mao, D; Zhou, S.; Wu, M.; Wu, W.; Liu, B. Visualization and In Situ Ablation of Intracellular Bacterial Pathogens through Metabolic Labeling. Angew. Chem. Int. Ed. 2020, 59, 9288.

(19) Aulić, S.; Bolognesi, M. L.; Legname, G. Small-Molecule Theranostic Probes: a Promising Future in Neurodegenerative Diseases. Int. J. Cell Biol. 2013, 2013, 150952.

(20) Pliquett, J.; Dubois, A.; Racoeur, C.; Mabrouk, N.; Amor, S.; Lescure, R.; Bettaieb, A.; Collin, B.; Bernhard, C.; Denat, F.; Bellaye, P. S.; Paul, C.; Bodio, E.; Goze, C. A Promising Family of Fluorescent Water-Soluble aza-BODIPY Dyes for in Vivo Molecular Imaging. Bioconjugate Chem. 2019, 30, 1061-1066.

(21) Bodio, E.; Denat, F.; Goze, C. BODIPY and aza-BODIPY Derivatives as Promising Fluorophores for in Vivo Molecular Imaging and Theranostic Applications. J. Porph. Phthal. 2019, 23, 1159-1183.

(22) Arkin, M. R.; Wells J. A. Small-Molecule Inhibitors of ProteinProtein Interactions: Progressing Towards the Dream. Nature Rev. Drug Discovery 2004, 3, 301-317.

(23) Almeida-Marrero, V.; van de Winckel, E.; Anaya-Plaza, E.; Torres, T.; de la Escosura, A. Porphyrinoid Biohybrid Materials as an Emerging Toolbox for Biomedical Light Management. Chem. Soc. Rev. 2018, 47, 7369-7400.

(24) Laranjo, M.; Campos Aguiar, M.; Pereira, N. A. M.; Brites, G.; Nascimento, B. F. O.; Brito, A. F.; Casalta-Lopes, J.; Gonçalves, A. C.; Sarmento-Ribeiro, A. B.; Pineiro, M.; Botelho, M. F.; Pinho e Melo, T. M. V. D. Platinum(II) Ring-Fused Chlorins as Efficient Theranostic Agents: Dyes for Tumor-Imaging and Photodynamic Therapy of Cancer. Eur. J. Med. Chem. 2020, 200, 112468.

(25) Zheng, Z.; Liu, H.; Zhai, S.; Zhang, H.; Shan, G.; Kwok, R. T. K.; Ma, C.; Sung, H. H. Y.; Williams, I. D.; Lam, J. W. Y.; Sing Wong, K.; Hu, X.; Zhong Tang, B. Highly Efficient Singlet Oxygen Generation, TwoPhoton Photodynamic Therapy and Melanoma Ablation by Rationally Designed Mitochondria-Specific Near-Infrared AlEgens. Chem. Sci. 2020, 11, 2494.

(26) Siriwibool, S.; Kaekratoke, N.; Chansaenpak, K.; Siwawannapong, K.; Panajapo, P.; Sagarik, K.; Noisa, P.; Lai, R.-Y.; Kamkaew, A. Near-Infrared Fluorescent pH Responsive Probe for Targeted Photodynamic Cancer Therapy. Sci. Rep. 2020, 10, 1283.

(27) Shi, C.; Wu J.; Pan, D. Review on Near-Infrared Heptamethine Cyanine Dyes as Theranostic Agents for Tumor Imaging, Targeting, and Photodynamic Therapy. J. Biomed. Opt. 2016, 21, 050901.

(28) Sun, W.; Guo, S.; Hu, C.; Fan, J.; Peng, X. Recent Development of Chemosensors Based on Cyanine Platforms. Chem. Rev. 2016, 116, 7768-7817.

(29) Ji, C.; Cheng, W.; Yuan, Q.; Müllen, K.; Yin, M. From Dyestuff Chemistry to Cancer Theranostics: The Rise of Rylenecarboximides. Acc. Chem. Res. 2019, 52, 2266-2277.

(30) Dale and Caro, Brit. Patent No. 3307, 1863. 
(31) Solodar, W. E.; Monaha, A. R. The synthesis and Spectroscopic Characterization of Indulin 6B Tetrasulfonate. Can. J. Chem. 1976, 54, 2909-2914 and references therein.

(32) Roy, S. K.; Samanta, S.; Sinan, M.; Ghosh, P.; Goswami, S. Aerial Oxidation of Protonated Aromatic Amines. Isolation, X-ray Structure, and Redox and Spectral Characteristics of N-Containing Dyes. J. Org. Chem. 2012, 77, 10249-10259.

(33) Berneth, H. ULLMANN'S Encyclopedia of Industrial Chemistry 2012, Wiley-VCH Verlag GmbH \& Co. KGaA, Weinheim.

(34) Shimizu, T.; Miyamoto, E.; Shishido, M. Jpn. Kokai Tokkyo Koho, 2011, JP 2011138030A.

(35) Raue, R.; Beecken, H. 1987, Ger. Offen. DE 3615571 A1 19871112.

(36) Zhu, X.; Zhao, M.; Hong, Y.; Ren, W.; Chen, J. Faming Zhuanli Shenqing, 2016, CN 105273349 A 20160127.

(37) Schurig, P.; Wichert, P.; Mueller, W.; Hentzschel, J.; Prezewowsky, E.; Klepzig, W. Ger. (East), 1991, DD 289897 A7 19910516.

(38) Wada, H.; Kondo, F.; Takahashi, Y.; Hasegawa, H.; Ishii, K. Jpn. Kokai Tokkyo Koho, 1973, JP 48056252 A 19730807.

(39) Curtis, B.; Payne, T. J.; Ash, D. E.; Mohanty, D. K. Secondary Amines Containing one Aromatic Nitro Group: Preparation, Nitrosation, Sustained Nitric Oxide Release, and the Synergistic Effects of Released Nitric Oxide and an Arginase Inhibitor on Vascular Smooth Muscle Cell Proliferation. Bioorg. Med. Chem. 2013, 21, 1123-1135.

(40) Zhang, N.-Q.; Li, P.; Dong, J.; Chen, H.-Y. Phenazinium Methyl Sulfate. Acta Crystallogr. E 2012, 68, o2101.

(41) Li, M.; Sun, W.; Tian, R.; Cao, J.; Tian, Y.; Gurram, B.; Fan, J.; Peng, X. Smart J-Aggregate of Cyanine Photosensitizer with the Ability to Target Tumor and Enhance Photodynamic Therapy Efficacy. Biomaterials, 2021, 269, 120532.

(42) Pascal, S.; Denis-Quanquin, S.; Appaix, F.; Duperray, A.; Grichine, A.; Le Guennic, B.; Jacquemin, D.; Cuny, J.; Chi, S.-H.; Perry, J. W.; van der Sanden, B.; Monnereau, C.; Andraud, C.; Maury, O. KetoPolymethines: a Versatile Class of Dyes with Outstanding Spectroscopic Properties for in Cellulo and in Vivo Two-Photon Microscopy Imaging. Chem. Sci. 2017, 8, 381-394.

(43) Pascal, S.; David, S.; Andraud, C.; Maury, O. Near-Infrared Dyes for Two-Photon Absorption in the Short-Wavelength Infrared: Strategies Towards Optical Power Limiting. Chem. Soc. Rev. 2021, in press, doi: 10.1039/D0CS01221A.

(44) Pascal, S.; Haefele, A.; Monnereau, C.; Charaf-Eddin, A.; Jacquemin, D.; Le Guennic, B.; Andraud C.; Maury, O. Expanding the Polymethine Paradigm: Evidence for the Contribution of a Bis-Dipolar Electronic Structure. J. Phys. Chem. A 2014, 118, 4038-4047.

(45) Pascal, S.; Siri, O. Benzoquinonediimine Ligands: Synthesis, Coordination Chemistry and Properties. Coord. Chem. Rev. 2017, 350, 178-195.

(46) Pascal, S.; Lavaud, L.; Azarias, C.; Canard, G.; Giorgi, M.; Jacquemin, D.; Siri, O. Controlling the Canonical/Zwitterionic Balance Through Intramolecular Proton Transfer: a Strategy for Vapochromism. Mater. Chem. Front. 2018, 2, 1618-1625.

(47) Chen, Z.; Bert, M.; Pascal, S.; Canard, G.; Siri, O. Versatile Transamination in Quinonediimine Chemistry: Towards a Novel Class of Water Soluble UV/Violet Chromophores. Tetrahedron Lett. 2019, 60, 151024.

(48) Longevial, J.-F.; Chen, Z.; Pascal, S.; Canard, G.; Jacquemin, D.; Siri, O. Stabilization of a $12-\pi$ Electrons Diamino-Benzoquinonediimine Tautomer. Chem. Commun. 2021, 57, 548-551.
(49) Yang, N.; Weinfeld, M.; Lemieux, H.; Montpetit, B.; Goping, S. Photo-Activation of the Delocalized Lipophilic Cation D112 Potentiates Cancer Selective ROS Production and Apoptosis. Cell. Death Dis. 2017, 8 , e2587.

(50) Zong, W.-X.; Rabinowitz, J. D.; White, E., Mitochondria and Cancer. Mol Cell. 2016, 61, 667-676.

(51) Simon, P.; Lavaud, L.; Azarias, C.; Varlot, V.; Canard, G.; Giorgi, M.; Jacquemin, D.; Siri, O. Brouwer, A. M. Azacalixquinarenes: From Canonical to (Poly-)Zwitterionic Macrocycles. J. Org. Chem. 2019, 84, 1387-1397.

(52) Stallivieri, A.; Colombeau, L.; Jetpisbayeva, G.; Moussaron, A.; Myrzakhmetov, B.; Arnoux, P.; Acherar, S.; Vanderesse, R.; Frochot, C. Folic acid conjugates with photosensitizers for cancer targeting in photodynamic therapy: Synthesis and photophysical properties. Bio.Med. Chem. 2017, 25, 1-10.

(53) Brouwer, A. M. Standards for Photoluminescence Quantum Yield Measurements in Solution. Pure Appl. Chem. 2011, 83, 22132228.

(54) D'Aléo, A.; Felouat, A.; Heresanu, V.; Ranguis, A.; Chaudanson, D.; Karapetyan, A.; Giorgi, M.; Fages, F. Two-photon excited fluorescence of BF2 complexes of curcumin analogues: toward NIR-toNIR fluorescent organic nanoparticles. J. Mater. Chem. C 2014, 2, 5208-5215.

(55) Zhao, Y.; Truhlar, D. The M06 Suite of Density Functionals for Main Group Thermochemistry, Thermochemical Kinetics, Noncovalent Interactions, Excited States, and Transition Elements: Two New Functionals and Systematic Testing of Four M06-Class Functionals and 12 Other Functionals. Theor. Chem. Acc. 2008, 120, 215-241.

(56) Jacquemin, D.; Planchat, A.; Adamo, C.; Mennucci, B., TD-DFT Assessment of Functionals for Optical 0-0 Transitions in Solvated Dyes. J. Chem. Theory Comput. 2012, 8, 2359-2372.

(57) Chen, Z.; Wannere, C. S.; Corminboeuf, C.; Puchta, R.; Schleyer, P. v. R., Nucleus-Independent Chemical Shifts (NICS) as an Aromaticity Criterion. Chem. Rev. 2005, 105, 3842-3888.

(58) M. J. Frisch, G. W. Trucks, H. B. Schlegel, G. E. Scuseria, M. A. Robb, J. R. Cheeseman, G. Scalmani, V. Barone, G. A. Petersson, H. Nakatsuji, X. Li, M. Caricato, A. V. Marenich, J. Bloino, B. G. Janesko, R. Gomperts, B. Mennucci, H. P. Hratchian, J. V. Ortiz, A. F. Izmaylov, J. L. Sonnenberg, D. Williams-Young, F. Ding, F. Lipparini, F. Egidi, J. Goings, B. Peng, A. Petrone, T. Henderson, D. Ranasinghe, V. G. Zakrzewski, J. Gao, N. Rega, G. Zheng, W. Liang, M. Hada, M. Ehara, K. Toyota, R. Fukuda, J. Hasegawa, M. Ishida, T. Nakajima, Y. Honda, O. Kitao, H. Nakai, T. Vreven, K. Throssell, J. A. Montgomery, Jr., J. E. Peralta, F. Ogliaro, M. J. Bearpark, J. J. Heyd, E. N. Brothers, K. N. Kudin, V. N. Staroverov, T. A. Keith, R. Kobayashi, J. Normand, K. Raghavachari, A. P. Rendell, J. C. Burant, S. S. Iyengar, J. Tomasi, M. Cossi, J. M. Millam, M. Klene, C. Adamo, R. Cammi, J. W. Ochterski, R. L. Martin, K. Morokuma, O. Farkas, J. B. Foresman, and D. J. Fox, Gaussian, Inc., Wallingford CT, 2016.

(59) Rhee, Y. M.; Head-Gordon, M. Scaled Second-Order Perturbation Corrections to Configuration Interaction Singles: Efficient and Reliable Excitation Energy Methods. J. Phys. Chem. A 2007, 111, 5314-5326.

(60) Krylov, A. I.; Gill, P. M. W. Q-Chem: An Engine for Innovation. WIREs Comput. Mol. Sci. 2013, 3, 317-326. 